\title{
Article \\ Impact of Temperature and Water on Seed Germination and Seedling Growth of Maize (Zea mays L.)
}

\author{
Hussein Khaeim *DiD, Zoltán Kende, Márton Jolánkai, Gergó Péter Kovács (D), Csaba Gyuricza and Ákos Tarnawa
}

check for

updates

Citation: Khaeim, H.; Kende, Z.; Jolánkai, M.; Kovács, G.P.; Gyuricza, C.; Tarnawa, Á. Impact of Temperature and Water on Seed Germination and Seedling Growth of Maize (Zea mays L.). Agronomy 2022, 12, 397. https://doi.org/10.3390/ agronomy12020397

Academic Editor: Jose Maria Barrero

Received: 31 December 2021 Accepted: 3 February 2022

Published: 5 February 2022

Publisher's Note: MDPI stays neutral with regard to jurisdictional claims in published maps and institutional affiliations.

Copyright: (C) 2022 by the authors. Licensee MDPI, Basel, Switzerland. This article is an open access article distributed under the terms and conditions of the Creative Commons Attribution (CC BY) license (https:// creativecommons.org/licenses/by/ $4.0 /)$.
Institute of Agronomy, Hungarian University of Agriculture and Life Sciences, Páter Károly u.1, 2100 Gödöllő, Pest, Hungary; kende.zoltan@uni-mate.hu (Z.K.); jolankai.marton@uni-mate.hu (M.J.); kovacs.gergo.peter@uni-mate.hu (G.P.K.); gyuricza.csaba@uni-mate.hu (C.G.); tarnawa.akos@uni-mate.hu (Á.T.) * Correspondence: hussein.khaeim@qu.edu.iq; Tel.: +36-302209300

\begin{abstract}
Germination and seedling development are essential stages in a plant's life cycle, greatly influenced by temperature and moisture conditions. The aim of this study was to determine maize (Zea mays L.) seeds' germination and seedling development under various abiotic stresses. Eight different temperature levels, 5, 10, 15, 20, 25, 30, 35, and $40{ }^{\circ} \mathrm{C}$, were used. Drought and waterlogging stresses were tested using 30 water levels based on one-milliliter intervals and as percentages of thousand kernel weight (TKW) at 20 and $25^{\circ} \mathrm{C}$. Seedling density and the use of antifungals were also examined. Temperature significantly affected germination duration and seedling growth, and $20{ }^{\circ} \mathrm{C}$ was found to be ideal with an optimal range of less than $30{ }^{\circ} \mathrm{C}$. Germination occurred at $25 \%$ of the TKW. The optimal water range for seedling growth was higher and broader than the range for germination. Seed size assisted in defining germination water requirements and providing an accurate basis. The present research established an optimum water supply range of $150-325 \%$ of the TKW for maize seedling development. A total of 6 seeds per $9 \mathrm{~cm}$ Petri dish may be preferable over greater densities. The technique of priming seeds with an antifungal solution before planting was observed to have a better effect than applying it in the growth media.
\end{abstract}

Keywords: Zea mays L.; maize; germination; seedling growth; germination time; germination water uptake

\section{Introduction}

Maize is one of the most important crops worldwide, and it is a staple cereal crop grown globally under a broad spectrum of soil and climatic conditions in temperate and tropical regions [1-3]. It is a nutritional, globally essential cereal crop that ranks first in production ahead of wheat and rice production $[3,4]$. Maize is not only consumed directly in the human diet but is also extensively utilized in biofuels; animal feed; and a wide range of industrial products, including syrup and corn starch [5-8]. The grains of maize contain nearly $72 \%$ starch, $10 \%$ protein, and $4 \%$ fat, providing an energy density of $1.53 \mathrm{MJ} 100 \mathrm{~g}^{-1}[6,9]$. Maize is a $\mathrm{C}_{4}$ crop species that belongs to the Poaceae family and is moderately sensitive to abiotic stresses, such as drought and temperature [10,11]. Since it is used worldwide in different ecosystems, the maize crop confronts a wide range of environmental abiotic stresses, including drought and increased temperatures because of climate change, which results in numerous yield losses [9,12]. Abiotic stress and soil and environmental conditions may reduce seed germination percentage meanwhile can cause adaptation to induced stress $[13,14]$.

Germination is a physiological process that initiates and develops a seedling by triggering a cascade of biological and biochemical reactions $[12,15]$. In the early stages of germination, known as imbibition, seeds absorb water rapidly, causing the seed coat to expand and soften at optimal temperatures [16,17]. Next, the seed's inner physiological activities are activated, and the seed's respiration starts $[17,18]$. Finally, the broken seed 
coats allow for the initiation of radicles and plumula. Therefore, it starts with water uptake by the quiescent dry seed and is accomplished by radicle emergence through elongation of the embryo axis $[16,19]$. This process involves a series of organized physiological and morphogenetic processes, including seed energy transfer, endospermic nutrient ingestion, and physiological and metabolic alterations [20,21]. The primary indications of germination are the restoration of critical activities, such as transcription, translation, and DNA repair, followed by cell elongation and division $[22,23]$.

Germination affects both the ultimate production and quality of maize [1]. Fundamentally, plants grow from a single seed into a plant [24,25]. Germination is controlled by the interplay of environmental factors, the physiological status of the seeds, and the germ [26,27]. The need for the various abiotic factors depends primarily on the genotype in response to these surrounding abiotic factors and these abiotic factors as a collective [17]. Maize germination requires favorable environmental conditions, and a specific range of these factors is necessary for optimal germination [28,29]. Conditions including temperature, light, and water availability influence germination [26,30]. The seeds' physiological reaction to overlapping extrinsic abiotic factors determines propagation success; thus, seed germination reflects population size, distribution, and abundance [27,31]. Germination does not need these abiotic variables individually since the demand for one component is dependent on the requirement of another, as shown for light overlapping temperature [32,33].

Successful production requires the growth of sturdy, well-developed seedlings, and one of the main goals of seedling production is to produce a viable plant from any single seed [34,35]. The availability and mobility of endosperm storage resources are essential determinants in seedling establishment $[36,37]$. Enzymic activity is required for endospermicreserved carbohydrates and lipid degradation to mobilize conserved resources during germination and early seedling growth [38,39]. Temperature and water availability significantly affect the biological and biochemical enzymic activities in germination and seedling growth stages $[2,33,34]$.

Temperature is one of the most necessary factors for seed germination, and it affects all individual reactions and stages of germination [33,40,41]. The cell energy status and some enzymes' activity (e.g., lipase, alanine aminotransferase, aspartate aminotransferase, and especially ribonuclease) change as the temperature increases and the ATP content rises [39]. The rate of protein synthesis decreases as the temperature level increases [40,42]. Temperature stress enhances the transcription, translation, and activity of ROS-scavenging enzymes in maize and results in the buildup of $\mathrm{H}_{2} \mathrm{O}_{2}$ [41]. The optimum temperature results in germination in the shortest time possible [43-45]. Since germination involves several stages, each has its cardinal temperature scale; the temperature response can differ during the germination period because of its complexity $[33,44]$. The temperature reaction of a seed depends on variety, seed quality, the length of time after harvest, and some other factors $[45,46]$. During germination, temperature changes significantly impact respiration and sugar metabolism. The homeostasis of reactive oxygen species (ROS) necessary for seed germination is disrupted by abnormal respiration [31,43,47]. Temperature plays a significant role in specifying seed germination duration, which means the time from subjecting a seed to water to the initiation of germination [46].

Water is necessary to hydrate protoplasmic metabolism activities, provide dissolved $\mathrm{O}_{2}$ to the seed embryo, soften the seed's outer coat, and improve seed permeability [33,38]. Water aids in the rupturing of the seed and converts the insoluble endospermic-stored materials into soluble status through enzyme activation, breakdown, and translocation and reserving storage materials in the endosperm and then translocating them to the growing embryo [38,48-51]. Water contributes to the subsequent germination metabolic stages, and it's level has more complicated effects on germination [8,52]. Water stress lowers enzymatic activity, which has a detrimental impact on carbohydrate metabolism, decreases water potential and soluble calcium and potassium, and alters the hormones of seeds [33,51,53]. Maize seeds are described as being low in moisture and metabolically dormant in their 
quiescence state. Therefore, the seeds may retain minimal metabolic activity during storage to ensure long-term survival [52].

The purpose of this research was to determine the germination potential of maize seeds under various moisture and temperature conditions, as well as the optimum number of seeds per Petri dish and levels of antifungal application. Therefore, this study included four main objectives: the first was (1) to investigate the effects of temperatures on germination, germination duration, and the seedling growth of maize seeds at eight different levels of temperature, and the second was (2) to determine the minimum, optimum, and maximum water amount required for germination based on the volume of water amounts of one-milliliter intervals and the thousand kernel weight (TKW). This technique was used to investigate the following null hypothesis: "the difference in seed weight and size has no effect on germination when the amount of water is constant". Therefore, we aimed to prove the following alternative hypothesis's validity: "the water necessary for germination and seedling growth differs depending on the size and weight of the seedlings". In theory, larger seeds need more water to develop than smaller ones. Thus, if the alternative hypothesis is true, it will provide a more precise technique for determining the optimum quantity of water required for germination and seedling growth. The size of the individual seed has importance in seed germination quality. Large-sized seeds of pigeon pea have been observed to have a higher ratio of germination [53]. The third objective was (3) to investigate the effect of the number of seeds and seedling density in a Petri dish on germination percentage and to open the Petri dish's top cover. Opened Petri dishes have a variety of adverse consequences, including moisture loss and contamination exposure. This section was designed to address the following question: "Do seed number and seedling density affect the germination percentage and seedling performance when applying the same amount of water?". The fourth objective was (4) to investigate the effect of using the seed priming technique before planting or adding an antifungal to the growth media on seedling growth.

This study provides essential information regarding germination requirements, and it investigates tolerance to a range of environmental temperatures and drought stresses.

\section{Materials and Methods}

This research investigated temperature, drought and waterlogging, and seedling density effects on germinating vigor and seedling development. In addition, fungal growth inhabitation was also studied. The seeds of a regionally widely used variety of Hungarian maize called Margitta were obtained from a producer. The most significant benefit of the Margitta hybrid is the very fast loss of water. The FAO number falls in the middle of the 300 group; this means a higher potential yield, but due to the fast loss of water, it ripens earlier than others in the same group. Margitta has a robust appearance and ripening on a green stem. Typically, the cobs bend down while ripening. Due to its remarkable stress tolerance, this hybrid's optimal sowing and harvesting range are very wide. This dentiform maize hybrid plants at a density of 65-70,000 plant/ha, the number of seed rows on a cob is $16-18$ with a seed-cob ratio of $86.8 \%$, and the length of a cob is $21-22 \mathrm{~cm}$. The research was split into four experiments, carried out as described in the subsections below.

\subsection{Temperature Experiment}

This research examined the germination of maize seeds at eight different temperatures: $5,10,15,20,25,30,35$, and $40^{\circ} \mathrm{C}$. The media were prepared; the Petri dishes were labeled, and each one was filled with ten maize seeds and subjected to the same quantity of distilled water, $9 \mathrm{~mL}$, after the distilled water was tested for conductivity, which was $1.5 \mu \mathrm{mhos} / \mathrm{cm}$. The number of non-germinated seeds was counted, and all seedlings' radicle and plumule lengths were measured. The measurement started when around $75 \%$ of the seedlings in the Petri dishes (PDs) reached the length of $1 \mathrm{~cm}$. Daily, four Petri dishes were taken out of the chamber for physical measurements at each temperature level. 


\subsection{Water Amount Experiment}

In sterile Petri dishes with a $9 \mathrm{~cm}$ diameter lined with a single sterile filter paper, maize seeds were subjected to 13 distilled water amounts based on milliliter intervals and 16 distilled water amounts based on TKW. Maize seeds were exposed to 12 distilled water amounts based on milliliter intervals and 16 distilled water amounts based on TKW in sterile Petri plates with a $9 \mathrm{~cm}$ diameter lined with a single sterile filter paper. Table 1 presents 30 water amount treatments for both considered bases. $235.2 \mathrm{~g}$.

$$
\mathrm{TKW} \times \text { Seed } \mathrm{n} / 100,000=1 \% \text { of the proposed water amount }
$$

$$
235.2 \times 10=2352,2352 / 100,000=0.02352
$$

\begin{tabular}{|c|c|c|c|c|c|}
\hline \multicolumn{2}{|c|}{ Amount of Water Based on $1 \mathrm{~mL}$ Interval } & \multicolumn{4}{|c|}{ Amount of Water Based on the TKW \% } \\
\hline $\begin{array}{l}\text { a Treatment } \\
\text { Number }\end{array}$ & b Water Amount (mL) & $\begin{array}{l}\text { a Treatment } \\
\text { Number }\end{array}$ & $\begin{array}{l}{ }^{\mathrm{c}} \text { Proposed \% of } \\
\text { Water Amount }\end{array}$ & $\begin{array}{c}\mathrm{d} \text { Amount } \\
\text { of Water }(\mathrm{mL})\end{array}$ & $\begin{array}{l}\text { e Rounded Amount } \\
\text { of Water }(\mathrm{mL})\end{array}$ \\
\hline 1 & 0 & 14 & $25 \%$ & 0.588 & 0.6 \\
\hline 2 & 1 & 15 & $50 \%$ & 1.176 & 1.2 \\
\hline 3 & 2 & 16 & $75 \%$ & 1.765 & 1.75 \\
\hline 4 & 3 & 17 & $100 \%$ & 2.352 & 2.35 \\
\hline 5 & 4 & 18 & $125 \%$ & 2.94 & 2.95 \\
\hline 6 & 5 & 19 & $150 \%$ & 3.528 & 3.55 \\
\hline 7 & 6 & 20 & $175 \%$ & 4.116 & 4.20 \\
\hline 8 & 7 & 21 & $200 \%$ & 4.704 & 4.70 \\
\hline 9 & 8 & 22 & $225 \%$ & 5.292 & 5.30 \\
\hline 10 & 9 & 23 & $250 \%$ & 5.88 & 5.90 \\
\hline 11 & 10 & 24 & $275 \%$ & 6.468 & 6.50 \\
\hline 12 & 11 & 25 & $300 \%$ & 7.056 & 7.00 \\
\hline \multirow[t]{4}{*}{13} & 12 & 27 & $325 \%$ & 7.644 & 7.65 \\
\hline & & 28 & $350 \%$ & 8.232 & 8.25 \\
\hline & & 29 & $375 \%$ & 8.82 & 8.80 \\
\hline & & 30 & $400 \%$ & 9.408 & 9.40 \\
\hline
\end{tabular}

Table 1. The experimental treatments based on the bases' milliliter intervals and TKW \%.

a The treatment number, which totaled 30 treatments, on the two water bases, ${ }^{b}$ the applied water amount based on $1 \mathrm{~mL}$ intervals from 1 to $12 \mathrm{~mL},{ }^{c}$ the proposed percentage of water in $\mathrm{ml}$ regarding the TKW in $\mathrm{g},{ }^{\mathrm{d}}$ the amount of water in $\mathrm{ml}$ corresponding to the proposed percentage of water to TKW, and ${ }^{\mathrm{e}}$ the rounded amount of water to the closest available pipette digit.

The Equation (1) [54,55] result represents 1\%. This outcome was multiplied by the proposed percentage for each water treatment, as shown in Table 1. Petri dishes were labeled, and 10 seeds were placed in each one with 5 replicates for each of the 30 treatments. This experiment was conducted in one set at a constant chamber temperature of $20{ }^{\circ} \mathrm{C}$ and another set at $25^{\circ} \mathrm{C}$. Physical measurements and evaluations were conducted after an incubation period of 10 days. Petri dishes were taken out of the chambers, and radicle length and plumule length were measured for all seedlings, in addition to counting the number of non-germinated seeds. These radicles and plumules were then labeled and subjected to $65{ }^{\circ} \mathrm{C}$ for $48 \mathrm{~h}$ in an oven. Finally, the radicles and plumules of the ten seedlings of each experimental unit were weighed, and the dry weights were obtained using a high-precision 3-digit digital scale.

\subsection{Seed Number Experiment}

This section of the experiment was designed to investigate the effect of the number of seeds on germination performance and seedling growth when applying the same amount of water. Four seed sets, 6, 8, 10, and 12 per PD, were incubated in a germination chamber at a constant temperature of $20^{\circ} \mathrm{C}$, and another four seed sets of the same numbers were incubated at $25^{\circ} \mathrm{C}$. They were supplied with the same amount of distilled water, $6 \mathrm{~mL}$. Ten replications were carried out for each treatment of each set to decrease the experiment's experimental error and increase the accuracy of the overall measurements. After ten days of incubation, they were taken out of the chamber for physical measurements of the proposed 
parameters. The measured parameters were classified into five categories: number of nongerminated seeds, started to germinate, germinated seeds with only radicle, seedling with a short plumule (shorter than approximately $4 \mathrm{~cm}$ ), and normal seedling. These classifications were created in order to obtain an aggregated value following Equation $(2)[54,55]$ :

$$
\text { Aggregated value }=(\mathrm{NO}-\mathrm{G} \times 0)+(\mathrm{S} \times 0.1)+(\mathrm{R} \times 0.25)+(\mathrm{SP} \times 0.65)+(\mathrm{NP} \times 1)
$$

where NO-G is non-germinated seeds, $\mathrm{S}$ is the start to initiate germination, $\mathrm{R}$ is the number of seeds germinated with radicle only, SP is the number of seeds germinated with short plumules, NP is the number of seeds germinated with normal plumule length.

\subsection{Antifungal Experiment}

A fungicide, Amistar Xtra, in different concentrations, two different techniques, and Hypo were used to investigate their effect on inhibiting fungal growth in Petri dishes. The active agents for this fungicide are $200 \mathrm{~g} / \mathrm{L}$ azoxystrobin and $80 \mathrm{~g} / \mathrm{L}$ cyproconazole, which Syngenta produces. The first technique was to apply 4 different concentrations of the fungicide, that is, $10,100,1000$, and $10,000 \mathrm{ppm}$, to the growth media. The other technique was to sterilize the seeds into the prepared solutions of 1000 ppm of Amistar Xtra and $5 \%$ of Hypo, separately, for 3 min; afterward, they were rinsed with distilled water. Two sets of ten replications for each treatment were incubated at each temperature of 20 and $40{ }^{\circ} \mathrm{C}$. Physical measurements and evaluations were conducted after the incubation period of 10 days. The Petri dishes were taken out of the growth chambers, radicle length and plumule length were measured for all seedlings, and the number of germinated seeds was counted.

\subsection{Statistical Analysis}

The given results and presented data are expressed as a mean value for each subexperimental section. Analysis of variance (ANOVA) and Fisher's test of least significant differences were used to determine significant differences at the $5 \%$ probability level for the water quantity experiment, seedling density experiment, and antifungal growth experiment using computing programs (GenStat twelfth edition, GenStat Procedure Library Release PL20.1m, and MS Excel 365). A sigmoid curve model was applied using statistical computing programs (J.M.P. Pro 13.2.1 of S.A.S. by SAS Institute, Cary, NC, USA and MS Excel 365) to fit the data and plot the best-fit temperature levels. The data were checked for normality using Skewness and Kurtosis in SPSS v27, IBM, New York, NY, USA.

\section{Results}

Based on the data calculated (Table 2), as the Skewness and Kurtosis values are between -0.5 and +0.5 , we can state that the curve is approximately symmetric [56] based on the histogram (Figure 1).

Table 2. Normality of the data referred by Skewness and Kurtosis tests.

\begin{tabular}{lccc}
\hline & & Valid & 65 \\
\cline { 3 - 4 } & & Missing & $\mathbf{1}$ \\
\hline & Mean & & 0.212966 \\
& Skewness & 0.292 \\
& Std. error of Skewness & 0.297 \\
& Kurtosis & 0.232 \\
& b Std. error of Kurtosis & 0.586 \\
\hline
\end{tabular}

${ }^{\mathrm{a}}$ The number of statistical measurements; ${ }^{\mathrm{b}}$ the standard error of the Kurtosis test of data normality. 


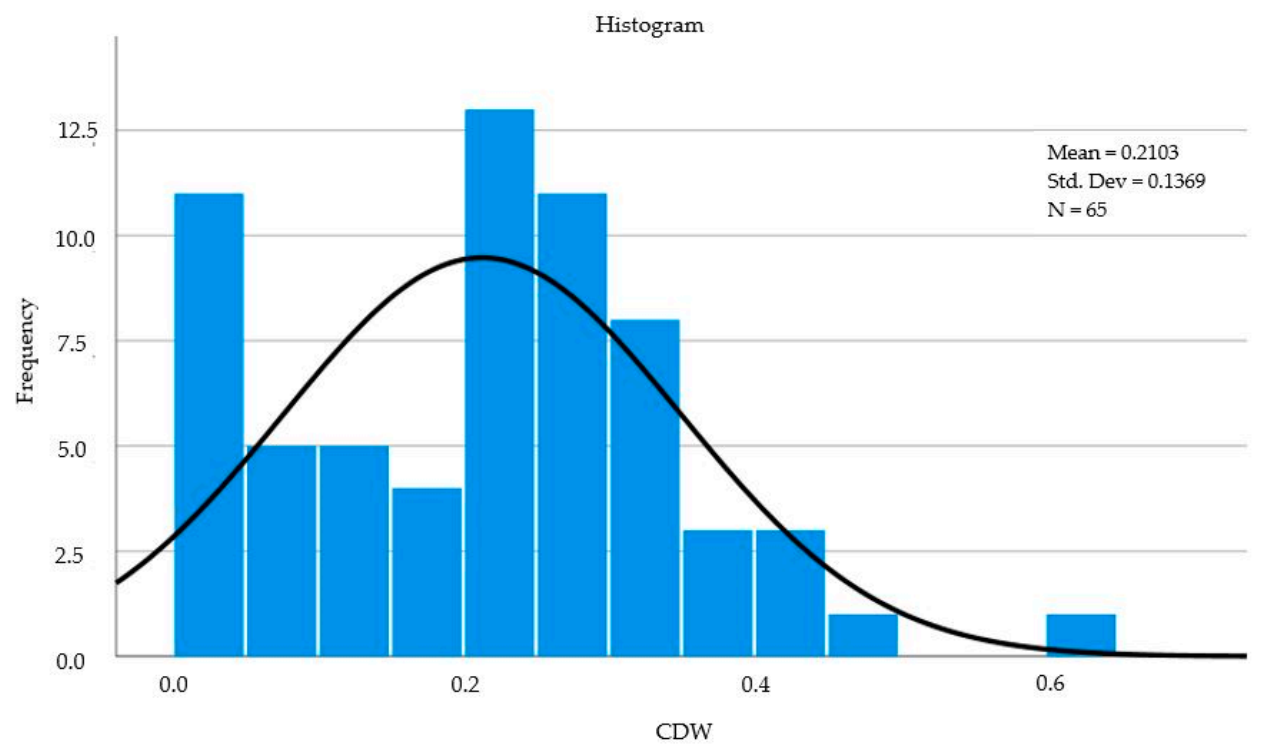

Figure 1. The distribution of the data. CDW is the corrected dry weight.

\subsection{Temperature Experiment}

\subsubsection{Germination Duration}

The standard measurement point for germination evaluation in this study was when $75 \%$ of the seeds reached a plumule length of $1 \mathrm{~cm}$. In the temperature gradient experiment of $20,25,30$, and $35^{\circ} \mathrm{C}$, which rapidly initiated germination, the seeds were determined to reach the standard measurement point the fastest, within $48 \mathrm{~h}$ (Figure 2). The seeds at $15^{\circ} \mathrm{C}$ took longer; that is, it took them seven days from the start of the treatment. At $10{ }^{\circ} \mathrm{C}$, the seeds needed the most extended period to initiate germination; that is, it took them 34 days to reach the standard measurement point (Figure 2). Maize seeds failed to germinate at $5{ }^{\circ} \mathrm{C}$; they were monitored for 45 days and at $40{ }^{\circ} \mathrm{C}$. The same seeds were further tested at $20^{\circ} \mathrm{C}$. The results showed that the germs died and were cooked over at $40{ }^{\circ} \mathrm{C}$; however, $30 \%$ of the seeds subjected to $5{ }^{\circ} \mathrm{C}$ germinated. The percentage difference within the range of germination between the lower and upper limits was $177.778 \%$. Discarding $10{ }^{\circ} \mathrm{C}$ and the temperature degrees of 20,25 , and $30^{\circ} \mathrm{C}$ resulted in minor margin differences in germination duration, followed by $15^{\circ} \mathrm{C}$, which required more extended time.

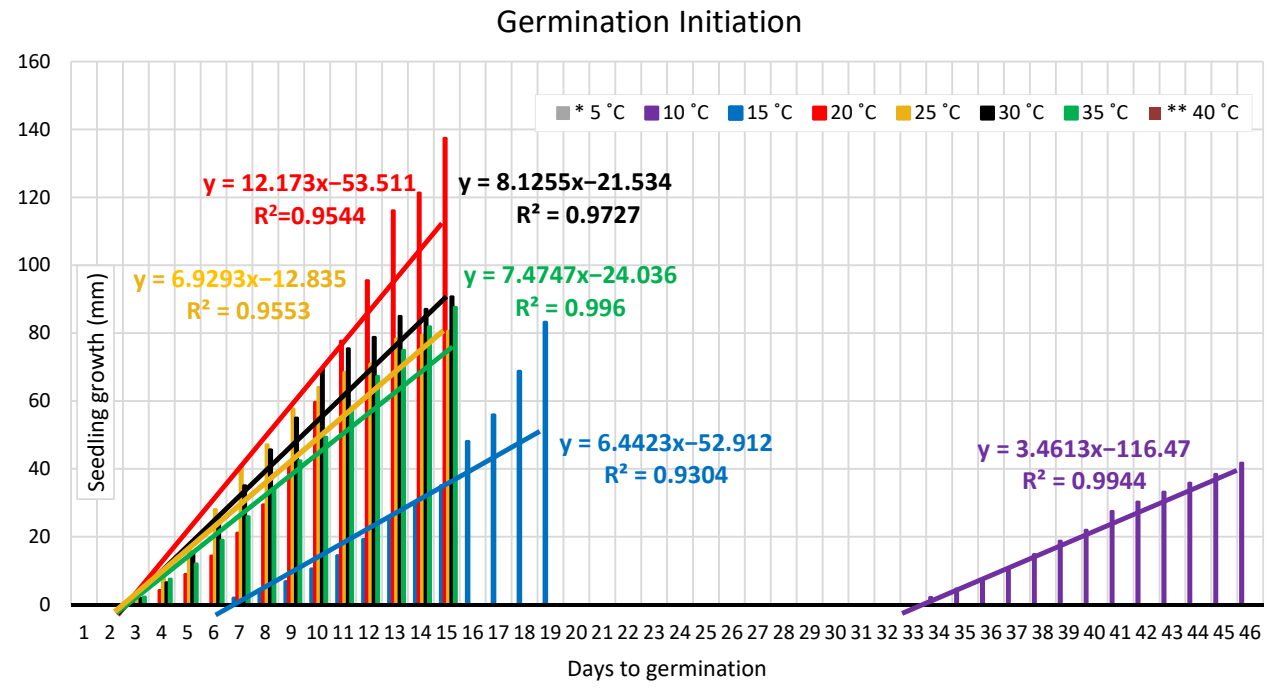

Figure 2. Duration from planting to germination initiation and seedling growth. The * and ** represent 5 and $40^{\circ} \mathrm{C}$ (respectively) which are not presented on the graph because their values are zero (no germination). 


\subsubsection{Seedling Growth}

The temperature gradient experiment established that, at $20{ }^{\circ} \mathrm{C}$, seedling growth had the best performance and the most remarkable growth rate compared to the other constant temperatures of $5,10,15,25,30,35$, and $40{ }^{\circ} \mathrm{C}$ (Figure 3). It is the optimal temperature for seedling development with $y$-value $=12.173 x-53.511$ (Figure 2). In the same pattern, but with slower growth, performance was shown at $15^{\circ} \mathrm{C}$ with $\mathrm{y}$-value $=6.4423 \mathrm{x}-52.912$. Figure 3 shows that seedling development at $10{ }^{\circ} \mathrm{C}$ is the most negligible and requires a much longer development time, with $y$-value $=3.4613 x-116.47$ (Figure 2). A similar growth pattern to that of the $10{ }^{\circ} \mathrm{C}$ treatment was shown at $35{ }^{\circ} \mathrm{C}$, with $\mathrm{y}$-value $=7.4747 \mathrm{x}-24.036$, but at $35^{\circ} \mathrm{C}$ it started germination a few days earlier (Table 3 ). Slightly identical growth development appeared at 25 and $30^{\circ} \mathrm{C}$ when in the early seedling stage; they grew faster, followed by accelerated growth drops because of the negative effect of fungal growth (Figure 3). There was no germination at both 5 and $40{ }^{\circ} \mathrm{C}$; the seedling growth chart shows them with zero values (Figure 3).

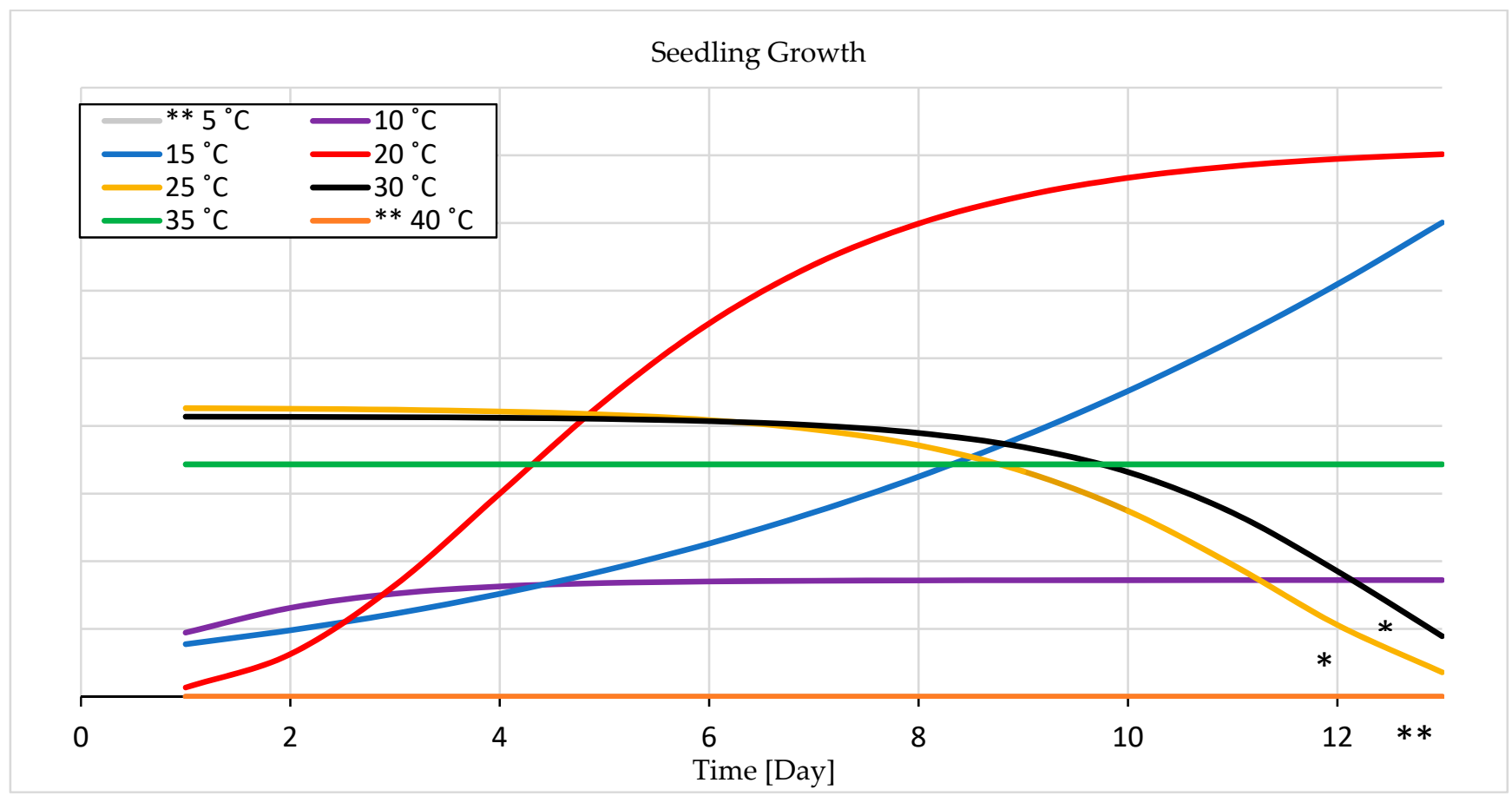

Figure 3. Seedling growth in response to temperature. ${ }^{*}$ growth dropped down because of fungal growth at favorable temperature conditions. ${ }^{* *}$ they are not shown on the graph because their value is zero (no seedling growth).

The plumule and radicle of the seedling developed similarly at and around the optimum temperature range, but their growth behavior varied as the temperature arrow crossed the optimal growth range tails in either direction (Figures 4 and 5). Under conditions where the temperature scope exceeded the optimal range, the plumule grew more rapidly than the radicle, particularly during the very early development stage (Figure 4). However, the radicle seemed to have a distinctly different pattern and temperature requirement than the plumule since it developed better in a lower temperature than the optimal range of the whole seedling growth, particularly in the later stage (Figure 5). Plumule development and growth were the greatest at the temperature level of $20^{\circ} \mathrm{C}$ and the lowest at $10^{\circ} \mathrm{C}$. The optimal temperature for plumule and radicle development was $20^{\circ} \mathrm{C}$, followed by $15{ }^{\circ} \mathrm{C}$. There was no germination at both 5 and $40^{\circ} \mathrm{C}$; the plumule and radicle growth development charts present them with zero values (Figures 4 and 5). 


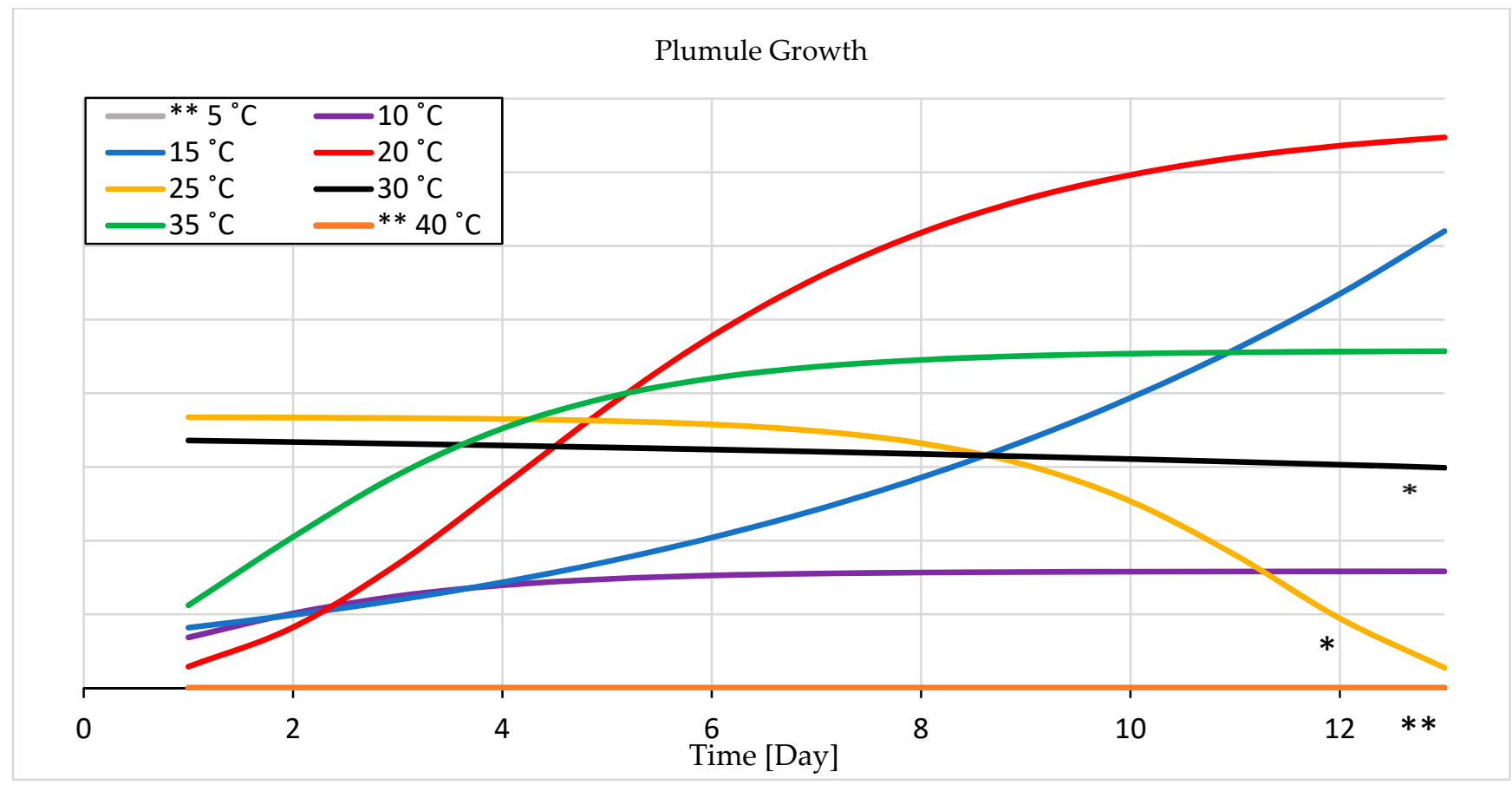

Figure 4. Plumule growth in response to temperature. ${ }^{*}$ growth dropped down because of fungal growth at favorable temperature conditions. ${ }^{* *}$ they are not shown on the graph because their value is zero (no plumule growth).

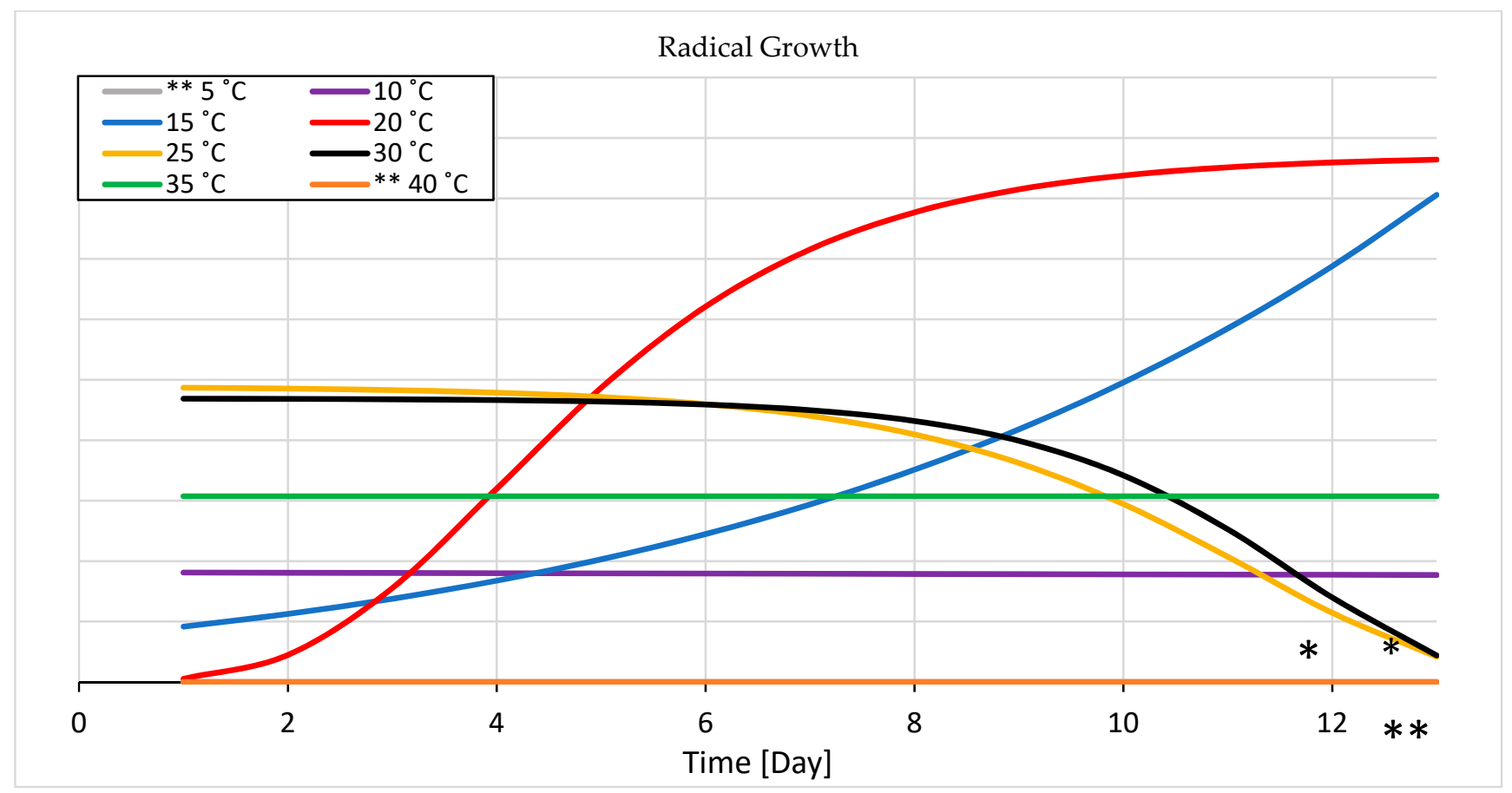

Figure 5. Radicle growth in response to temperature. * growth dropped down because of fungal growth at favorable temperature conditions. ${ }^{* *}$ they are not shown on the graph because their value is zero (no radicle growth).

\subsection{Water Amount Experiment}

This sub-experiment was conducted employing two water bases, one-milliliter intervals, and the percentage of the TKW at a total of 30 treatments at temperature levels of 20 and $25^{\circ} \mathrm{C}$ (Table 2). The results in Table 3 present significant differences among the water 
amount potential of $0-12 \mathrm{~mL}$ at $20^{\circ} \mathrm{C}$ for all variables, namely, the number of germinated seeds, radicle length, plumule length, total seedling length, total seedling dry weight, corrected total seedling dry weight, which were obtained by subtracting the number of non-germinated seeds, radicle dry weight, and plumule dry weight. Regarding the same water base and one-milliliter intervals from 0 to $12 \mathrm{~mL}$, the same significant differences were shown for all variables at $25^{\circ} \mathrm{C}$, but with different patterns to those at $20{ }^{\circ} \mathrm{C}$ (Table 3 and Figure 6).

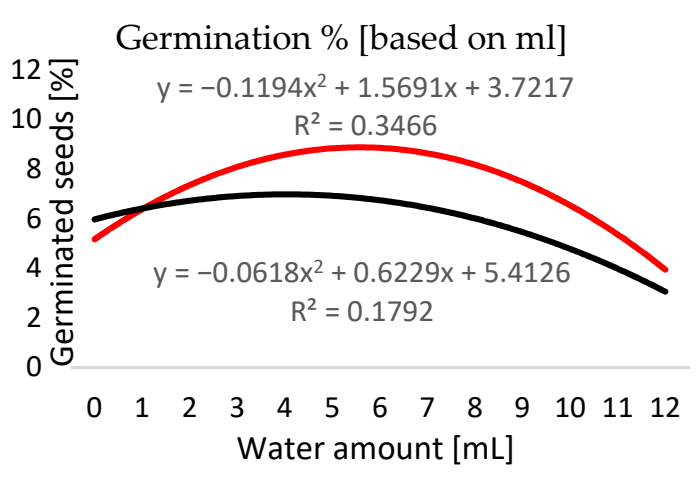

(A)

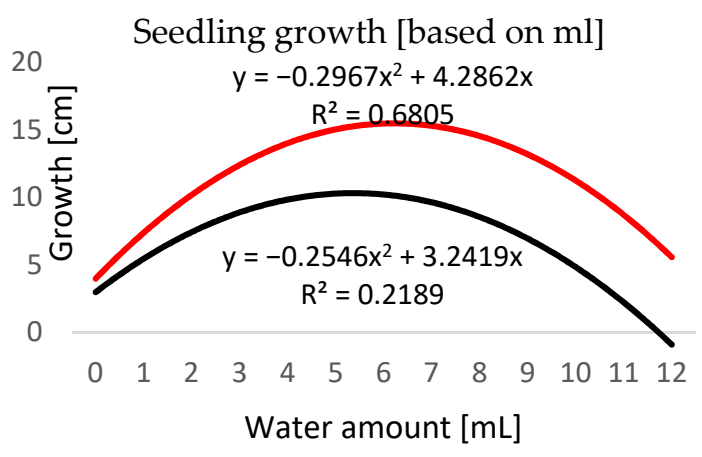

(C)

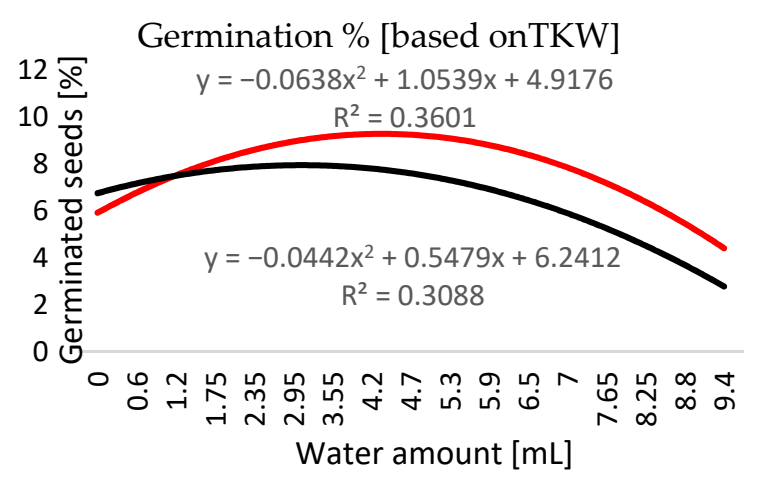

(B)

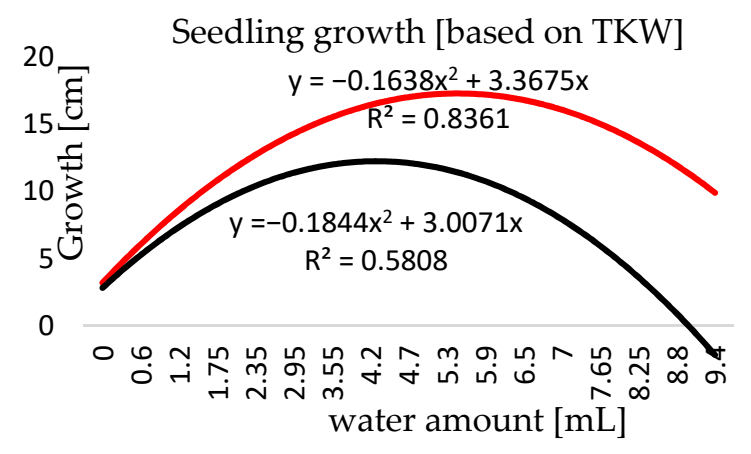

(D)

Figure 6. Seedling response to the different amounts of water at 2 temperature levels, 20 and $25{ }^{\circ} \mathrm{C}$. (A) Germination using different amounts of water based on $1 \mathrm{~mL}$ intervals (1-12). (B) Germination using different amounts of water based on percentages of TKW. (C) Seedling growth using different amounts of water based on $1 \mathrm{~mL}$ intervals (1-12). (D) Seedling growth using different amounts of water based on percentages of TKW.

The number of germinated seeds increased sharply and significantly as the water level increased until the potential water amount was reached, followed by a slight decrease as the water amount increased (Tables 3-6 and Figure 6A). The same pattern was shown when applying a water amount based on the TKW with significant differences (Tables 4 and 6, and Figure 6B). The germination percentage at $20{ }^{\circ} \mathrm{C}$ differed slightly, with a better performance than that at $25^{\circ} \mathrm{C}$ (Figure 6A,B). Maize seeds can be germinated with a minimal amount of water, $0.60 \mathrm{~mL}$; Tables 4 and 6 represent $25 \%$ of the TKW (Table 2). The optimal range for germination was $0.60-5.3 \mathrm{~mL}$ per $9 \mathrm{~cm}$ Petri dish (Figure 6B), representing 125-225\% of the TKW (Table 2). In parallel, regarding the other base of water, with a $1 \mathrm{ml}$ interval of water at the exact temperature of $25^{\circ} \mathrm{C}$, the optimal range for germination was similar at $1-6 \mathrm{~mL}$. This means that the applied water based on the TKW is more precise for the optimization of water demand for germination (Table 3). The optimal germination range at $20{ }^{\circ} \mathrm{C}$ was 1-6 mL, which is broader than the range at $25^{\circ} \mathrm{C}$ of $1-4 \mathrm{~mL}$, which can be attributed to the temperature effect overlapping the water amount (Tables 3 and 5). 
Water stress plays a vital role in seedling growth. When applying the lowest amount of water, the seedling length presented the lowest mean values, and as the amount of water increased, seedling development significantly increased (Tables 3-6, Figures 7 and 8). The optimal range of water amount for seedling growth was $3.55-7.65 \mathrm{~mL}$ per $9 \mathrm{~cm}$ Petri dish, representing $150-325 \%$ of the TKW at $20{ }^{\circ} \mathrm{C}$, and a narrower optimal range at 25 ${ }^{\circ} \mathrm{C}$ ranged from 2.35 to 5.30 , representing $100-225 \%$ of the TKW (Tables 4 and 6). In parallel, significant seedling length development started with $2 \mathrm{~mL}$ of water according to the water application based on one-milliliter intervals at both temperature levels. The range of the optimal water amount at $20^{\circ} \mathrm{C}$ was $2-8 \mathrm{~mL}$, which is wider than the one at 25 ${ }^{\circ} \mathrm{C}$ of $2-4 \mathrm{~mL}$ (Tables 3 and 5). This means that moisture percentage based on the TKW is more accurate and reliable. Figures $7 \mathrm{~A}, \mathrm{~B}$ and $8 \mathrm{~A}, \mathrm{~B}$ present the optimal ranges for seedling development for both water supplement bases at 20 and $25^{\circ} \mathrm{C}$. Therefore, water stress significantly reduces seedlings' vigor, and seedling length increases dramatically at the starting point of the optimal range.

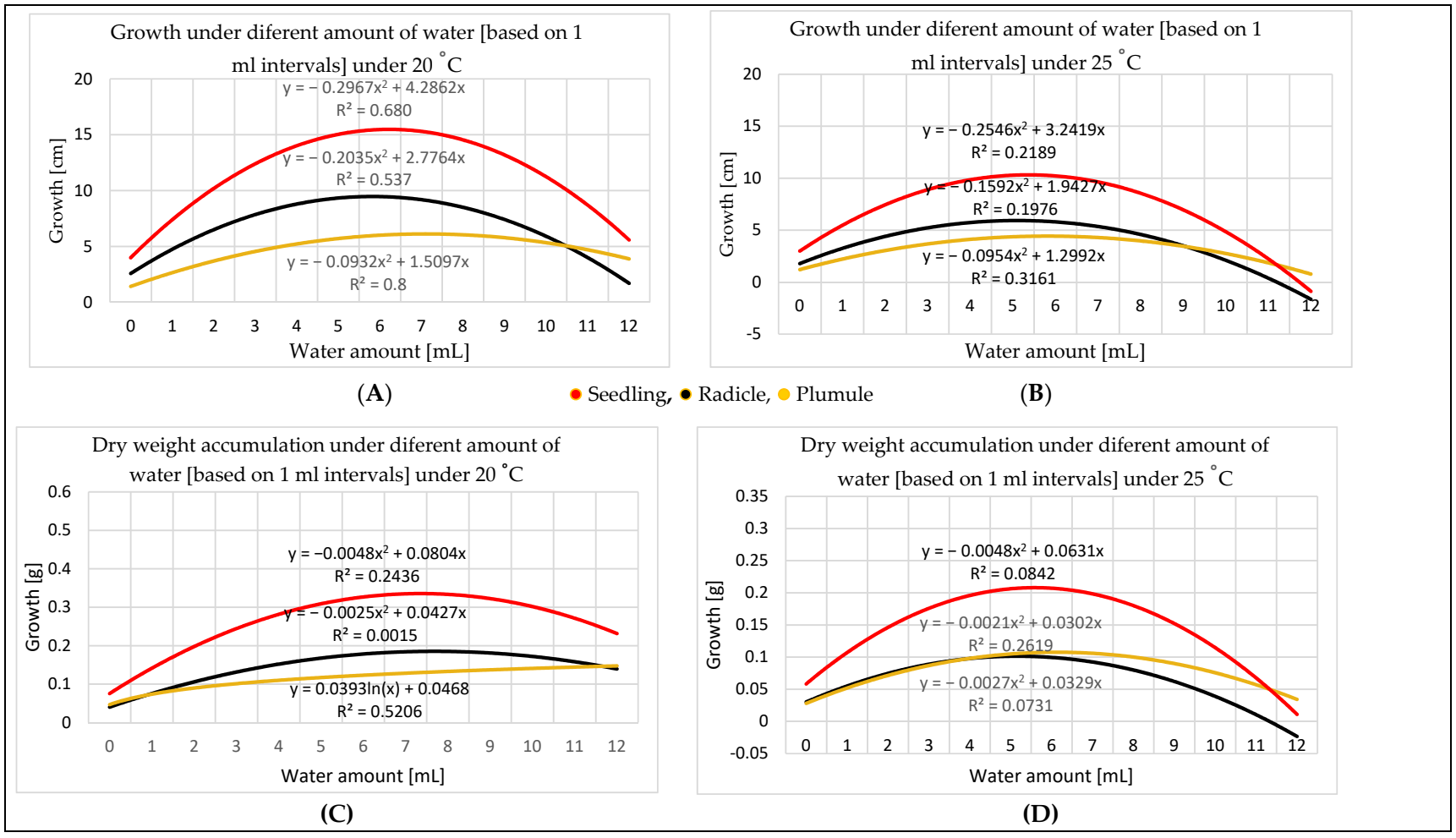

Figure 7. Seedlings, plumule, and radicle response to the different amounts of water at 2 temperature levels, 20 and $25^{\circ} \mathrm{C}$. (A) Growth using different amounts of water based on $1 \mathrm{~mL}$ intervals (1-12) at $20^{\circ} \mathrm{C}$. (B) Growth using different amounts of water based on $1 \mathrm{~mL}$ intervals (1-12) at $25{ }^{\circ} \mathrm{C}$. (C) Dry weight accumulation using different amounts of water based on $1 \mathrm{~mL}$ intervals $(1-12)$ at $20^{\circ} \mathrm{C}$. (D) Dry weight accumulation using different amounts of water based on $1 \mathrm{~mL}$ intervals (1-12) at $25^{\circ} \mathrm{C}$.

The variance analysis revealed significant variations in the lengths of the radicle and plumule for each of the applied water amounts. Radicle length gradually significantly increased as the amount of water increased (Tables 3-6). Thus, there is an optimal range for maize radicle growth, followed by a gradual decrease with a higher amount of water. Plumule growth and development followed a different pattern than the growth of the radicle. Therefore, it is worthwhile measuring the whole seedling; the radicle and the plumule statistically continued to be close to the optimal range as the amount of water increased than the lower amount of water (Figures 7A,B and 8A,B). Water stress and waterlogging have a greater effect on the roots than the plumules. The plumule seemed to 
develop better than the root in a slightly higher amount of water, $3-10 \mathrm{~mL}$, than the radicle, 1-8 mL (Table 3).

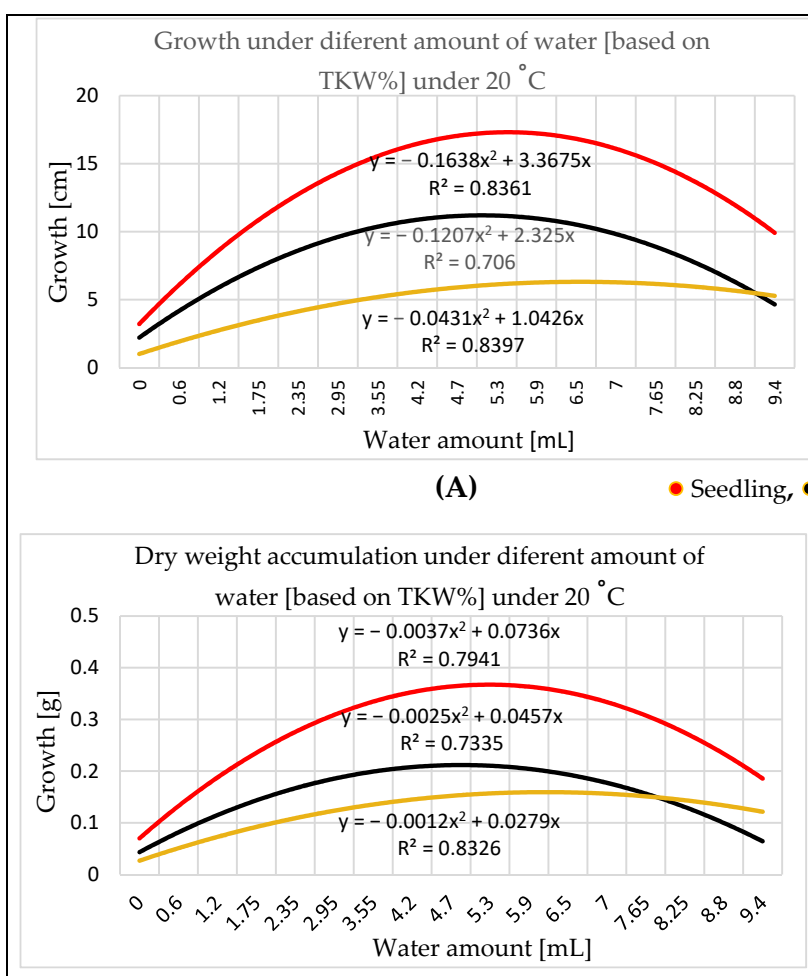

(C)

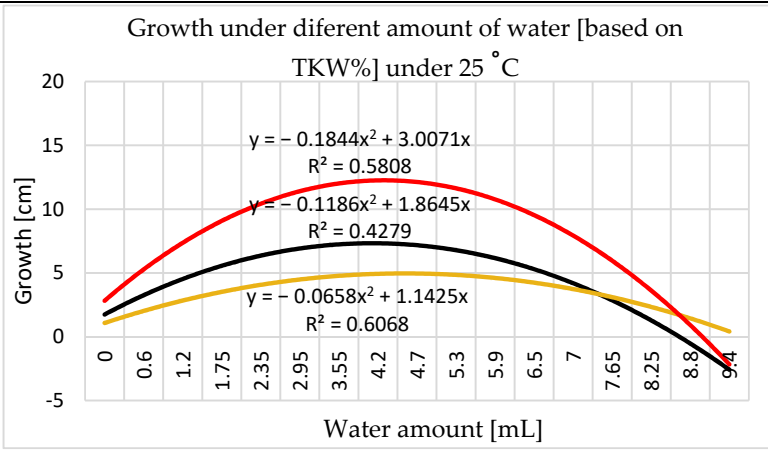

(B)



(D)

Figure 8. Seedlings, plumule, and radicle response to the different amounts of water at 2 temperature levels, 20 and $25^{\circ} \mathrm{C}$. (A) Growth using different amounts of water based on TKW\% at $20{ }^{\circ} \mathrm{C}$. (B) Growth using different amounts of water based on TKW\% at $25^{\circ} \mathrm{C}$. (C) Dry weight accumulation using different amounts of water based on TKW\% at $20^{\circ} \mathrm{C}$. (D) dry weight accumulation using different amounts of water based on TKW\% at $25^{\circ} \mathrm{C}$.

Another laboratory test is the dry weight test, which can evaluate seed vigor and seedling drought resistance. There were significant differences among the seedlings' accumulated dry matter with water availability (Tables 3-6). Dry matter accumulation occurred at the height of the optimal range of water for seedling growth to build a dry matter unit per time scale, and an increase in the water amount had no positive effect on the increase in the dry matter (Figures 7C,D and 8C,D). The seedlings' growth and development, when applying a higher water amount than the threshold range, were negatively slightly affected by the excess amount of water. This excess portion of water slowed the accumulation of dry matter in the maize seedlings. Therefore, the abiotic stresses drought and waterlogging negatively influenced dry matter accumulation.

\subsection{Seed Number Experiment}

The results of the statistical analysis of variance indicated no significant differences among the germination percentages with different treatments and seedling densities corresponding to the aggregated values of 6, 8, 10, and 12 maize seeds per Petri dish (Table 7). Furthermore, there were no significant differences among the subdivisions of the aggregated values, namely, seedlings with normal plumule growth, seedlings with short plumule growth, seedlings with radicle growth only, started to germinate seeds fraction, and the non-germinated seeds fraction. Therefore, since a higher seedling density than the optimum possessed a reverse effect when opening the Petri dish cover, and there were no significant differences between the four seed densities in use, it was concluded that a density of six seeds per Petri dish is better for maize germination tests in vitro. 
Table 3. Germination and seedling characteristic variables of Zea mays L. seeds respond to the water potential of $1 \mathrm{~mL}$ water amount intervals at $20{ }^{\circ} \mathrm{C}$.

\begin{tabular}{|c|c|c|c|c|c|c|c|c|}
\hline $\begin{array}{c}{ }^{1} \text { Water } \\
(\mathrm{mL})\end{array}$ & $\begin{array}{c}{ }^{2} \text { Germinated } \\
\text { Seeds }\end{array}$ & $\begin{array}{c}{ }^{3} \text { Radicle } \\
(\mathrm{cm})\end{array}$ & $\begin{array}{l}4 \text { Plumule } \\
(\mathrm{cm})\end{array}$ & $\begin{array}{c}{ }^{5} \text { Seedling } \\
(\mathrm{cm})\end{array}$ & $\begin{array}{c}{ }^{6} \text { Radicle } \\
\text { DW (g) }\end{array}$ & $\begin{array}{l}{ }^{7} \text { Plumule } \\
\text { DW (g) }\end{array}$ & $\begin{array}{c}{ }^{8} \text { Seedling } \\
\text { DW (g) }\end{array}$ & $\begin{array}{c}{ }^{9} \text { Corrected } \\
\text { DW (g) }\end{array}$ \\
\hline 0 & $0.00 \pm 0.00 \mathrm{f}$ & $0.00 \pm 0.00 \mathrm{e}$ & $0.00 \pm 0.00 c$ & $0.00 \pm 0.00 \mathrm{f}$ & $0.00 \pm 0.00 c$ & $0.00 \pm 0.00 \mathrm{~d}$ & $0.00 \pm 0.00 c$ & $0.00 \pm 0.00 \mathrm{f}$ \\
\hline 1 & $10.0 \pm 0.00 \mathrm{a}$ & $8.04 \pm 0.96 a b c$ & $1.35 \pm 0.39 c$ & $4.70 \pm 0.57 \mathrm{cde}$ & $0.17 \pm 0.02 b c$ & $0.07 \pm 0.02 c$ & $0.24 \pm 0.19 b$ & $0.237 \pm 0.02 b$ \\
\hline 3 & $9.20 \pm 0.84 \mathrm{ab}$ & $8.92 \pm 1.21 \mathrm{ab}$ & $5.46 \pm 0.48 \mathrm{ab}$ & $7.19 \pm 0.68 \mathrm{abcd}$ & $0.18 \pm 0.05 b$ & $0.14 \pm 0.02 \mathrm{ab}$ & $0.29 \pm 0.07 b$ & $0.291 \pm 0.08 \mathrm{~b}$ \\
\hline 4 & $9.60 \pm 0.55 a$ & $10.90 \pm 2.08 \mathrm{a}$ & $6.16 \pm 0.73 a b$ & $8.53 \pm 1.33 \mathrm{a}$ & $0.19 \pm 0.04 b$ & $0.14 \pm 0.03 \mathrm{ab}$ & $0.31 \pm 010 \mathrm{~b}$ & $0.321 \pm 0.08 \mathrm{~b}$ \\
\hline 5 & $8.80 \pm 1.30 \mathrm{ab}$ & $9.18 \pm 4.22 \mathrm{ab}$ & $5.56 \pm 1.88 \mathrm{ab}$ & $7.37 \pm 2.95 \mathrm{abc}$ & $0.15 \pm 0.06 \mathrm{bc}$ & $0.13 \pm 0.03 \mathrm{ab}$ & $0.33 \pm 0.08 \mathrm{ab}$ & $0.255 \pm 0.12 c$ \\
\hline 6 & $8.00 \pm 1.41 \mathrm{abc}$ & $9.14 \pm 3.32 \mathrm{ab}$ & $5.88 \pm 1.21 \mathrm{ab}$ & $7.51 \pm 2.20 \mathrm{ab}$ & $0.15 \pm 0.06 \mathrm{bc}$ & $0.14 \pm 0.03 \mathrm{ab}$ & $0.28 \pm 0.10 \mathrm{~b}$ & $0.244 \pm 0.10 \mathrm{def}$ \\
\hline 8 & $7.40 \pm 1.67 \mathrm{bcd}$ & $7.90 \pm 2.58 \mathrm{abc}$ & $7.16 \pm 1.48 \mathrm{a}$ & $7.53 \pm 1.99 \mathrm{ab}$ & $0.14 \pm 0.04 \mathrm{bc}$ & $0.16 \pm 0.03 a$ & $0.26 \pm 0.14 b$ & $0.232 \pm 0.10$ ef \\
\hline 9 & $6.60 \pm 2.07 \mathrm{cde}$ & $4.86 \pm 2.66 \mathrm{~cd}$ & $4.84 \pm 1.49 \mathrm{~b}$ & $4.85 \pm 2.05$ bcde & $0.10 \pm 0.05 b c$ & $0.13 \pm 0.05 \mathrm{ab}$ & $0.30 \pm 0.07 b$ & $0.158 \pm 0.09 \mathrm{~cd}$ \\
\hline 10 & $5.60 \pm 2.30 \mathrm{de}$ & $4.72 \pm 2.78 \mathrm{~cd}$ & $5.18 \pm 2.40 \mathrm{ab}$ & $4.95 \pm 2.57$ bcde & $0.09 \pm 0.04 \mathrm{bc}$ & $0.13 \pm 0.05 \mathrm{ab}$ & $0.22 \pm 0.09 \mathrm{~b}$ & $0.136 \pm 0.10$ ef \\
\hline 11 & $5.20 \pm 2.17 \mathrm{e}$ & $4.72 \pm 4.28 \mathrm{~cd}$ & $4.44 \pm 3.02 \mathrm{~b}$ & $4.58 \pm 3.61 \mathrm{de}$ & $0.41 \pm 0.46 \mathrm{a}$ & $0.10 \pm 0.08 \mathrm{bc}$ & $0.51 \pm 0.09 \mathrm{a}$ & $0.302 \pm 0.28 \mathrm{de}$ \\
\hline 12 & $6.00 \pm 2.55 \mathrm{cde}$ & $4.16 \pm 2.93 \mathrm{~d}$ & $4.42 \pm 2.95 b$ & $4.29 \pm 2.87 \mathrm{e}$ & $0.07 \pm 0.04 c$ & $0.11 \pm 0.06 \mathrm{abc}$ & $0.18 \pm 0.10 b c$ & $0.096 \pm 0.09 \mathrm{def}$ \\
\hline $\mathrm{LSD}^{*}$ & 2.07 & 3.49 & 2.26 & 2.78 & 0.172 & 0.054 & 0.20 & 0.053 \\
\hline
\end{tabular}

${ }^{*}$ Different lowercase letters (column) present significant differences between the means $(p<0.05)$, according to LSD multiple, starting sequentially with the letter (a) being the most significant; ${ }^{1}$ the amount of applied water per $9 \mathrm{~cm}$ diameter Petri dish $(\mathrm{mL}) ;^{2}$ the number of non-germinated seeds of the total examined seeds per treatment; ${ }^{3}$ the mean length of the radicles of each treatment $(\mathrm{cm}){ }^{4}$ the mean of the length of the plumules of each treatment $(\mathrm{cm}){ }^{5}$ the mean of the length of the seedling of each treatment $(\mathrm{cm}){ }^{6}{ }^{6}$ the means of the dry weight of the radicles of each treatment $(\mathrm{g}) ;^{7}$ the means of the dry weight of the plumules of each treatment $(\mathrm{g}){ }^{8}{ }^{8}$ the means of the dry weight of the seedlings of each treatment $(\mathrm{g})$; and ${ }^{9}$ the mean of the corrected dry weight, which is the dry weight of the actual existing seedling after discarding the non-germinated ones.

Table 4. Germination and seedling characteristic variables of Zea mays L. seeds respond to the water potential of the TKW base at $20{ }^{\circ} \mathrm{C}$.

\begin{tabular}{|c|c|c|c|c|c|c|c|c|c|}
\hline $\begin{array}{c}1 \text { Water } \\
(\mathrm{mL})\end{array}$ & $\begin{array}{l}{ }^{2} \text { Water } \\
\text { (TKW) }\end{array}$ & $\begin{array}{c}{ }^{3} \text { Germinated } \\
\text { Seeds }\end{array}$ & $\begin{array}{c}{ }^{4} \text { Radicle } \\
(\mathrm{cm})\end{array}$ & $\begin{array}{l}5 \text { Plumule } \\
\text { (cm) }\end{array}$ & $\begin{array}{l}{ }^{6} \text { Seedling } \\
(\mathrm{cm})\end{array}$ & $\begin{array}{c}{ }^{7} \text { Radicle } \\
\text { DW (g) }\end{array}$ & $\begin{array}{l}{ }^{8} \text { Plumule } \\
\text { DW (g) }\end{array}$ & $\begin{array}{l}{ }^{9} \text { Seedling } \\
\text { DW (g) }\end{array}$ & $\begin{array}{c}{ }^{10} \text { Corrected } \\
\text { DW (g) }\end{array}$ \\
\hline 0 & $25 \%$ & $0.00 \pm 0.00 \mathrm{f}$ & $0.00 \pm 0.00 \mathrm{~h}$ & $0.00 \pm 0.00 \mathrm{e}$ & $0.00 \pm 0.00 \mathrm{~h}$ & $0.00 \pm 0.00 \mathrm{f}$ & $0.00 \pm 0.00 \mathrm{f}$ & $0.00 \pm 0.00 \mathrm{~g}$ & $0.00 \pm 0.00 \mathrm{~g}$ \\
\hline 0.60 & $50 \%$ & $10.0 \pm 0.00 \mathrm{a}$ & $6.74 \pm 0.92 \mathrm{fg}$ & $0.28 \pm 0.15 \mathrm{e}$ & $3.51 \pm 0.41 \mathrm{~g}$ & $0.07 \pm 0.01 \mathrm{e}$ & $0.03 \pm 0.02$ ef & $0.10 \pm 0.01 \mathrm{f}$ & $0.10 \pm 0.01 \mathrm{fg}$ \\
\hline 1.75 & $100 \%$ & $9.80 \pm 0.45 a$ & $8.12 \pm 0.80$ cdef & $2.24 \pm 0.67 \mathrm{~d}$ & $5.18 \pm 0.36 \mathrm{efg}$ & $0.18 \pm 0.01 \mathrm{abc}$ & $0.09 \pm 0.02 \mathrm{~d}$ & $0.23 \pm 0.02$ cde & $0.27 \pm 0.01 \mathrm{abcd}$ \\
\hline 2.35 & $125 \%$ & $9.60 \pm 0.55 \mathrm{a}$ & $9.36 \pm 0.97$ abcde & $4.82 \pm 1.61 c$ & $7.09 \pm 1.25$ bcde & $0.19 \pm 0.02 \mathrm{abc}$ & $0.13 \pm 0.03 \mathrm{bcd}$ & $0.32 \pm 0.03 \mathrm{abcd}$ & $0.31 \pm 0.04 \mathrm{ab}$ \\
\hline 2.95 & $150 \%$ & $9.00 \pm 0.00 \mathrm{abc}$ & $8.74 \pm 1.00$ bcdef & $5.14 \pm 0.38 \mathrm{abc}$ & $6.94 \pm 0.57$ bcde & $0.18 \pm 0.02 \mathrm{abc}$ & $0.14 \pm 0.00 \mathrm{abc}$ & $0.32 \pm 0.02 \mathrm{abcd}$ & $0.29 \pm 0.02 \mathrm{abc}$ \\
\hline 3.55 & $175 \%$ & $9.20 \pm 0.84 \mathrm{ab}$ & $10.28 \pm 0.87$ abcde & $5.94 \pm 0.70 \mathrm{abc}$ & $8.11 \pm 0.63 \mathrm{abcd}$ & $0.21 \pm 0.04 \mathrm{ab}$ & $0.17 \pm 0.01 \mathrm{a}$ & $0.38 \pm 0.05 \mathrm{a}$ & $0.35 \pm 0.05 \mathrm{a}$ \\
\hline 4.70 & $225 \%$ & $9.20 \pm 0.45 \mathrm{ab}$ & $11.40 \pm 0.72 \mathrm{ab}$ & $6.76 \pm 0.53 a$ & $9.08 \pm 0.46 \mathrm{ab}$ & $0.21 \pm 0.02 \mathrm{ab}$ & $0.16 \pm 0.01 \mathrm{ab}$ & $0.37 \pm 0.02 \mathrm{ab}$ & $0.34 \pm 0.01 \mathrm{a}$ \\
\hline 5.30 & $250 \%$ & $8.80 \pm 1.30 \mathrm{abcd}$ & $12.18 \pm 2.44 \mathrm{a}$ & $6.68 \pm 1.47 \mathrm{ab}$ & $9.43 \pm 1.89 \mathrm{a}$ & $0.24 \pm 0.11 \mathrm{a}$ & $0.15 \pm 0.02 \mathrm{abc}$ & $0.38 \pm 0.12 \mathrm{a}$ & $0.34 \pm 0.10 \mathrm{a}$ \\
\hline 5.90 & $275 \%$ & $7.60 \pm 1.80$ bcde & $10.38 \pm 3.50 \mathrm{abcd}$ & $6.76 \pm 1.96 \mathrm{a}$ & $8.57 \pm 2.65 \mathrm{abc}$ & $0.15 \pm 0.04 \mathrm{~cd}$ & $0.14 \pm 0.02 \mathrm{abc}$ & $0.29 \pm 0.05 \mathrm{bcd}$ & $0.23 \pm 0.10$ bcde \\
\hline
\end{tabular}


Table 4. Cont.

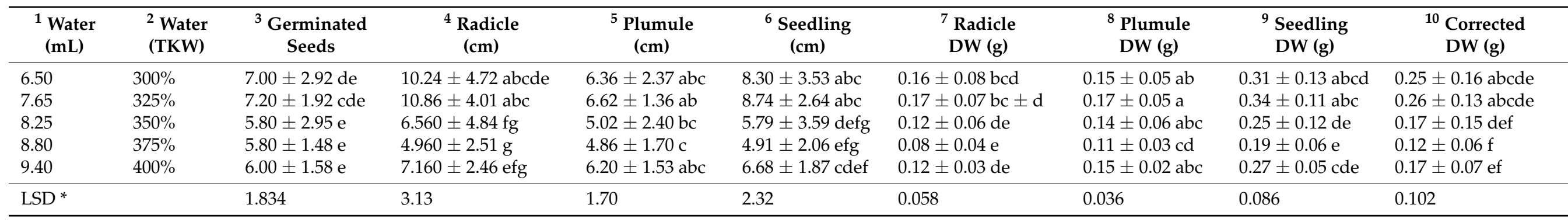

* Different lowercase letters (column) present significant differences between the means $(p<0.05)$, according to LSD multiple, starting sequentially with the letter (a) being the most significant; ${ }^{1}$ the amount of applied water per $9 \mathrm{~cm}$ diameter Petri dish $(\mathrm{mL}){ }^{2}$ percentage of water in relation to the TKW; ${ }^{3}$ the number of non-germinated seeds in the average of the total examined seeds per treatment; ${ }^{4}$ the mean length of the radicles of each treatment $(\mathrm{cm}) ;^{5}$ the mean of the length of the plumules of each treatment $(\mathrm{cm}) ;{ }^{6}$ the mean of the length of the seedling of each treatment $(\mathrm{cm}) ;{ }^{7}$ the means of the dry weight of the radicles of each treatment $(\mathrm{g}) ;{ }^{8}$ the means of the dry weight of the plumules of each treatment $(\mathrm{g}){ }^{9}{ }^{9}$ the means of the dry weight of the seedlings of each treatment $(\mathrm{g}) ;{ }^{10}$ the mean of the corrected dry weight $(\mathrm{g})$, which is the dry weight of the actual existing seedling after discarding the non-germinated ones.

Table 5. Germination and seedling characteristic variables of Zea mays L. seeds respond to the water potential of $1 \mathrm{~mL}$ water amount intervals at $25^{\circ} \mathrm{C}$.

\begin{tabular}{|c|c|c|c|c|c|c|c|c|}
\hline $\begin{array}{l}{ }^{1} \text { Water } \\
(\mathrm{mL})\end{array}$ & $\begin{array}{c}{ }^{2} \text { Germinated } \\
\text { Seeds }\end{array}$ & $\begin{array}{l}{ }^{3} \text { Radicle } \\
\text { (cm) }\end{array}$ & $\begin{array}{l}{ }^{4} \text { Plumule } \\
\text { (cm) }\end{array}$ & $\begin{array}{c}{ }^{5} \text { Seedling } \\
\text { (cm) }\end{array}$ & $\begin{array}{c}{ }^{6} \text { Radicle } \\
\text { DW (g) }\end{array}$ & $\begin{array}{l}{ }^{7} \text { Plumule } \\
\text { DW (g) }\end{array}$ & $\begin{array}{l}{ }^{8} \text { Seedling } \\
\text { DW (g) }\end{array}$ & $\begin{array}{c}{ }^{9} \text { Corrected } \\
\text { DW (g) }\end{array}$ \\
\hline 0 & $0.0 \pm 0.00 \mathrm{~g}$ & $0.00 \pm 0.00 \mathrm{f}$ & $0.00 \pm 0.00 \mathrm{f}$ & $0.00 \pm 0.00 \mathrm{~h}$ & $0.00 \pm 0.00 \mathrm{f}$ & $0.00 \pm 0.00 \mathrm{f}$ & $0.00 \pm 0.00 \mathrm{~g}$ & $0.00 \pm 0.00 \mathrm{f}$ \\
\hline 1 & $9.8 \pm 0.45 \mathrm{a}$ & $8.04 \pm 0.93 a$ & $2.34 \pm 0.26 \mathrm{de}$ & $5.19 \pm 0.44 \mathrm{bcd}$ & $0.15 \pm 0.03 \mathrm{ab}$ & $0.06 \pm 0.01 \mathrm{cde}$ & $0.11 \pm 0.01 \mathrm{bc}$ & $0.21 \pm 0.03 \mathrm{~b}$ \\
\hline 2 & $10 \pm 0.00 \mathrm{a}$ & $8.76 \pm 0.753$ & $4.82 \pm 0.48 \mathrm{abc}$ & $6.79 \pm 0.54 \mathrm{ab}$ & $0.18 \pm 0.01 \mathrm{a}$ & $0.11 \pm 0.01 \mathrm{ab}$ & $0.15 \pm 0.01 \mathrm{a}$ & $0.29 \pm 0.01 \mathrm{a}$ \\
\hline 3 & $8.2 \pm 0.45 b c$ & $7.50 \pm 1.07 \mathrm{ab}$ & $5.58 \pm 0.82 \mathrm{ab}$ & $6.54 \pm 0.86 a b c$ & $0.15 \pm 0.02 \mathrm{ab}$ & $0.13 \pm 0.02 \mathrm{a}$ & $0.14 \pm 0.02 \mathrm{ab}$ & $0.23 \pm 0.04 \mathrm{~b}$ \\
\hline 4 & $9.4 \pm 0.89 \mathrm{ab}$ & $9.16 \pm 1.92 \mathrm{a}$ & $6.02 \pm 0.65 \mathrm{a}$ & $7.59 \pm 1.13 \mathrm{a}$ & $0.12 \pm 0.03 \mathrm{~b}$ & $0.13 \pm 0.02 \mathrm{ab}$ & $0.13 \pm 0.02 \mathrm{ab}$ & $0.22 \pm 0.08 \mathrm{~b}$ \\
\hline 5 & $7.2 \pm 1.79 c$ & $4.90 \pm 4.39 \mathrm{bc}$ & $4.00 \pm 2.39 \mathrm{bcd}$ & $4.45 \pm 3.31$ cde & $0.06 \pm 0.05 c$ & $0.10 \pm 0.05 \mathrm{abcd}$ & $0.08 \pm 0.02 \mathrm{~cd}$ & $0.11 \pm 0.07 c$ \\
\hline 6 & $5.2 \pm 2.28 \mathrm{~d}$ & $3.54 \pm 2.95 \mathrm{~cd}$ & $4.06 \pm 2.74 \mathrm{abcd}$ & $3.80 \pm 2.81 \mathrm{def}$ & $0.06 \pm 0.05 c$ & $0.09 \pm 0.05 \mathrm{abcd}$ & $0.08 \pm 0.04$ cde & $0.04 \pm 0.01 \mathrm{def}$ \\
\hline 7 & $4.8 \pm 1.48 \mathrm{de}$ & $2.08 \pm 1.21 \mathrm{def}$ & $2.96 \pm 1.99 \mathrm{cde}$ & $2.52 \pm 1.58$ efg & $0.04 \pm 0.02$ cde & $0.07 \pm 0.04 \mathrm{bcd}$ & $0.05 \pm 0.03$ def & $0.05 \pm 0.03 \mathrm{def}$ \\
\hline 8 & $3.2 \pm 1.30 \mathrm{de}$ & $0.68 \pm 0.36$ ef & $1.00 \pm 0.66 \mathrm{ef}$ & $0.84 \pm 0.51 \mathrm{gh}$ & $0.01 \pm 0.01$ ef & $0.04 \pm 0.03 \mathrm{ef}$ & $0.02 \pm 0.02 \mathrm{fg}$ & $0.02 \pm 0.02 \mathrm{ef}$ \\
\hline 9 & $4.8 \pm 1.64 \mathrm{de}$ & $3.28 \pm 3.78$ cde & $3.72 \pm 2.67 \mathrm{bcd}$ & $3.50 \pm 3.14 \mathrm{def}$ & $0.05 \pm 0.06 \mathrm{~cd}$ & $0.11 \pm 0.07 \mathrm{abc}$ & $0.08 \pm 0.06 \mathrm{~cd}$ & $0.09 \pm 0.07 \mathrm{~cd}$ \\
\hline 10 & $3.8 \pm 0.84$ ef & $0.90 \pm 0.78$ ef & $2.38 \pm 1.20 \mathrm{de}$ & $1.64 \pm 0.94 \mathrm{fgh}$ & $0.02 \pm 0.01 \mathrm{df}$ & $0.07 \pm 0.03$ bcde & $0.04 \pm 0.02 \mathrm{ef}$ & $0.04 \pm 0.02 \mathrm{ef}$ \\
\hline 11 & $5.4 \pm 1.14 \mathrm{f}$ & $1.06 \pm 0.88$ ef & $2.18 \pm 1.25 \mathrm{de}$ & $1.62 \pm 1.04 \mathrm{fgh}$ & $0.03 \pm 0.01$ cdef & $0.07 \pm 0.04$ bcde & $0.05 \pm 0.03$ def & $0.05 \pm 0.03 \mathrm{de}$ \\
\hline 12 & $4.6 \pm 1.14 \mathrm{def}$ & $1.68 \pm 2.17 \mathrm{def}$ & $2.16 \pm 1.89 \mathrm{de}$ & $1.92 \pm 1.96 \mathrm{fgh}$ & $0.03 \pm 0.03$ cdef & $0.06 \pm 0.04 \mathrm{de}$ & $0.04 \pm 0.04$ ef & $0.04 \pm 0.05$ def \\
\hline $\mathrm{LSD}^{*}$ & 1.55 & 2.64 & 2.01 & 2.22 & 0.038 & 0.047 & 0.035 & 0.053 \\
\hline
\end{tabular}

* Different lowercase letters (column) present significant differences between the means $(p<0.05)$, according to LSD multiple, starting sequentially with the letter (a) being the most significant; ${ }^{1}$ the amount of applied water per $9 \mathrm{~cm}$ diameter Petri dish $(\mathrm{mL}) ;{ }^{2}$ the number of germinated seeds of the total examined seeds per treatment; ${ }^{3}$ the mean length of the radicles of each treatment $(\mathrm{cm}) ;{ }^{4}$ the mean of the length of the plumules of each treatment $(\mathrm{cm}) ;^{5}$ the mean of the length of the seedling of each treatment $(\mathrm{cm}){ }^{6}{ }^{6}$ the means of the dry weight of the radicles of each treatment $(\mathrm{g}) ;^{7}$ the means of the dry weight of the plumules of each treatment $(\mathrm{g}){ }^{8}{ }^{8}$ the means of the dry weight of the seedlings of each treatment $(\mathrm{g}) ;^{9}$ the mean of the corrected dry weight, which is the dry weight of the actual existing seedling after discarding the non-germinated ones. 
Table 6. Germination and seedling characteristic variables of Zea mays L. seeds respond to the water potential of the TKW base at $25^{\circ} \mathrm{C}$.

\begin{tabular}{|c|c|c|c|c|c|c|c|c|c|}
\hline $\begin{array}{l}1 \text { Water } \\
\text { (mL) }\end{array}$ & $\begin{array}{l}{ }^{2} \text { Water } \\
\text { (TKW) }\end{array}$ & $\begin{array}{c}{ }^{3} \text { Germinated } \\
\text { Seeds }\end{array}$ & $\begin{array}{c}{ }^{4} \text { Radicle } \\
\text { (cm) }\end{array}$ & $\begin{array}{l}5 \text { Plumule } \\
\text { (cm) }\end{array}$ & $\begin{array}{l}{ }^{6} \text { Seedling } \\
(\mathrm{cm})\end{array}$ & $\begin{array}{c}{ }^{7} \text { Radicle } \\
\text { DW (g) }\end{array}$ & $\begin{array}{l}{ }^{8} \text { Plumule } \\
\text { DW (g) }\end{array}$ & $\begin{array}{l}{ }^{9} \text { Seedling } \\
\text { DW (g) }\end{array}$ & $\begin{array}{c}{ }^{10} \text { Corrected } \\
\text { DW (g) }\end{array}$ \\
\hline 0 & $25 \%$ & $0.00 \pm 0.00 \mathrm{f}$ & $0.00 \pm 0.00 \mathrm{f}$ & $0.00 \pm 0.00 \mathrm{f}$ & $0.00 \pm 0.00 \mathrm{~h}$ & $0.00 \pm 0.00 \mathrm{e}$ & $0.00 \pm 0.00 \mathrm{f}$ & $0.00 \pm 0.00 \mathrm{i}$ & $0.00 \pm 0.00 \mathrm{~h}$ \\
\hline 0.60 & $50 \%$ & $10.0 \pm 0.00 \mathrm{a}$ & $7.08 \pm 0.88 \mathrm{bc}$ & $0.32 \pm 0.19$ ef & $3.70 \pm 0.38 \mathrm{de}$ & $0.07 \pm 0.01$ cde & $0.03 \pm 0.02$ ef & $0.10 \pm 0.01$ ef & $0.10 \pm 0.01$ def \\
\hline 1.75 & $100 \%$ & $9.80 \pm 0.45 \mathrm{a}$ & $8.50 \pm 0.59 \mathrm{ab}$ & $2.40 \pm 0.71 \mathrm{~cd}$ & $5.45 \pm 0.37 \mathrm{bcd}$ & $0.18 \pm 0.01 \mathrm{ab}$ & $0.09 \pm 0.02 \mathrm{~cd}$ & $0.28 \pm 0.02 \mathrm{a}$ & $0.27 \pm 0.01 \mathrm{a}$ \\
\hline 2.35 & $125 \%$ & $9.60 \pm 0.55 \mathrm{ab}$ & $9.98 \pm 0.90 \mathrm{a}$ & $5.64 \pm 0.51 \mathrm{a}$ & $7.81 \pm 0.38 \mathrm{a}$ & $0.16 \pm 0.03 \mathrm{abc}$ & $0.15 \pm 0.01 \mathrm{a}$ & $0.16 \pm 0.01 \mathrm{bcd}$ & $0.15 \pm 0.02 c$ \\
\hline 2.95 & $150 \%$ & $9.20 \pm 0.84 \mathrm{ab}$ & $8.62 \pm 2.47 \mathrm{ab}$ & $6.58 \pm 0.55 a$ & $7.60 \pm 1.40 \mathrm{a}$ & $0.11 \pm 0.04 \mathrm{bcd}$ & $0.13 \pm 0.02 \mathrm{ab}$ & $0.12 \pm 0.03$ cde & $0.11 \pm 0.03$ cde \\
\hline 3.55 & $175 \%$ & $8.20 \pm 1.79 \mathrm{abc}$ & $6.04 \pm 1.07 \mathrm{~cd}$ & $5.38 \pm 0.93 a$ & $5.71 \pm 0.99 \mathrm{bc}$ & $0.09 \pm 0.02$ bcde & $0.12 \pm 0.00 \mathrm{abc}$ & $0.11 \pm 0.01 \mathrm{def}$ & $0.09 \pm 0.02$ ef \\
\hline 4.70 & $225 \%$ & $6.80 \pm 2.86 \mathrm{~cd}$ & $5.62 \pm 2.94 \mathrm{~cd}$ & $5.00 \pm 2.22 \mathrm{ab}$ & $5.31 \pm 2.56 \mathrm{bcd}$ & $0.07 \pm 0.03$ cde & $0.10 \pm 0.03 \mathrm{bcd}$ & $0.08 \pm 0.03$ efg & $0.06 \pm 0.04 \mathrm{fg}$ \\
\hline 5.30 & $250 \%$ & $7.80 \pm 2.05 \mathrm{bc}$ & $7.16 \pm 3.29 b c$ & $6.02 \pm 2.16 \mathrm{a}$ & $6.59 \pm 2.71 \mathrm{ab}$ & $0.23 \pm 0.30 \mathrm{a}$ & $0.12 \pm 0.04 \mathrm{abcd}$ & $0.17 \pm 0.15 b c$ & $0.13 \pm 0.11 \mathrm{~cd}$ \\
\hline 5.90 & $275 \%$ & $5.00 \pm 1.58 \mathrm{de}$ & $4.10 \pm 2.00 \mathrm{de}$ & $5.12 \pm 1.39 \mathrm{a}$ & $4.61 \pm 1.70 \mathrm{~cd}$ & $0.04 \pm 0.02 \mathrm{de}$ & $0.10 \pm 0.04 \mathrm{bcd}$ & $0.07 \pm 0.03 \mathrm{efgh}$ & $0.04 \pm 0.02 \mathrm{gh}$ \\
\hline 6.50 & $300 \%$ & $3.80 \pm 0.84 \mathrm{e}$ & $1.20 \pm 1.01 \mathrm{f}$ & $1.84 \pm 2.84$ cde & $1.52 \pm 1.40 \mathrm{fgh}$ & $0.02 \pm 0.01 \mathrm{de}$ & $0.03 \pm 0.03$ ef & $0.02 \pm 0.02 \mathrm{hi}$ & $0.01 \pm 0.01 \mathrm{~h}$ \\
\hline 7.65 & $325 \%$ & $4.80 \pm 1.79 \mathrm{e}$ & $1.94 \pm 1.74$ ef & $2.46 \pm 2.22 \mathrm{~cd}$ & $2.20 \pm 1.98 \mathrm{efg}$ & $0.03 \pm 0.03 \mathrm{de}$ & $0.05 \pm 0.04 \mathrm{e}$ & $0.04 \pm 0.03 \mathrm{ghi}$ & $0.02 \pm 0.02 \mathrm{gh}$ \\
\hline 8.25 & $350 \%$ & $3.40 \pm 1.67 \mathrm{e}$ & $0.44 \pm 0.31 \mathrm{f}$ & $0.52 \pm 0.40$ ef & $0.48 \pm 0.34 \mathrm{gh}$ & $0.01 \pm 0.01 \mathrm{e}$ & $0.03 \pm 0.03$ ef & $0.02 \pm 0.02 \mathrm{hi}$ & $0.01 \pm 0.01 \mathrm{~h}$ \\
\hline 8.80 & $375 \%$ & $4.80 \pm 0.45 \mathrm{e}$ & $1.76 \pm 0.84 \mathrm{f}$ & $3.36 \pm 1.48 \mathrm{dc}$ & $2.56 \pm 1.13 \mathrm{ef}$ & $0.04 \pm 0.02 \mathrm{de}$ & $0.09 \pm 0.03 \mathrm{~d}$ & $0.06 \pm 0.03 \mathrm{fgh}$ & $0.03 \pm 0.01 \mathrm{gh}$ \\
\hline 9.40 & $400 \%$ & $5.20 \pm 2.95 \mathrm{de}$ & $0.60 \pm 0.26 \mathrm{f}$ & $1.14 \pm 0.75 \mathrm{def}$ & $0.87 \pm 0.50 \mathrm{fgh}$ & $0.02 \pm 0.01 \mathrm{de}$ & $0.04 \pm 0.02 \mathrm{e}$ & $0.03 \pm 0.02 \mathrm{hi}$ & $0.02 \pm 0.02 \mathrm{~h}$ \\
\hline $\mathrm{LSD}^{*}$ & & 1.950 & 2.25 & 1.67 & 1.86 & 0.098 & 0.034 & 0.055 & 0.043 \\
\hline
\end{tabular}

* Different lowercase letters (column) present significant differences between the means $(p<0.05)$, according to LSD multiple, starting sequentially with the letter (a) being the most significant; ${ }^{1}$ the amount of applied water per $9 \mathrm{~cm}$ diameter Petri dish $(\mathrm{mL}) ;^{2}$ percentage of water in relation to the TKW; ${ }^{3}$ the number of non-germinated seed portions in the average of the total examined seeds per each treatment; ${ }^{4}$ the mean length of the radicles of each treatment $(\mathrm{cm}) ;{ }^{5}$ the mean of the length of the plumules of each treatment $(\mathrm{cm}){ }^{6}{ }^{6}$ the mean of the length of the seedling of each treatment $(\mathrm{cm}) ;{ }^{7}$ the means of the dry weight of the radicles of each treatment $(\mathrm{g}){ }^{8}{ }^{8}$ the means of the dry weight of the plumules of each treatment $(\mathrm{g}){ }^{9}{ }^{9}$ the means of the dry weight of the seedlings of each treatment $(\mathrm{g}) ;{ }^{10}$ the mean of the corrected dry weight $(\mathrm{g})$, which is the dry weight of the actual existing seedling after discarding the non-germinated one. 
Table 7. Maize seeds' germination and seedling characteristic variables respond to the number of seeds per Petri dish.

\begin{tabular}{|c|c|c|c|c|c|c|}
\hline${ }^{1}$ Seeds (n) & $\begin{array}{c}{ }^{2} \text { Non-Germinated } \\
\text { seeds } \\
(\%)\end{array}$ & $\begin{array}{c}{ }^{3} \text { Started } \\
\text { germination } \\
(\%)\end{array}$ & $\begin{array}{c}{ }^{4} \text { Seedlings with } \\
\text { radicle only } \\
(\%)\end{array}$ & $\begin{array}{l}{ }^{5} \text { Seedlings with } \\
\text { a short plumule } \\
(\%)\end{array}$ & $\begin{array}{c}{ }^{6} \text { Seedlings with } \\
\text { normal plumule } \\
(\%)\end{array}$ & $\begin{array}{c}{ }^{7} \text { Aggregated } \\
\text { value } \\
(\%)\end{array}$ \\
\hline \multicolumn{7}{|c|}{$20^{\circ} \mathrm{C}$} \\
\hline 6 & $0.133 \pm 0.11$ & $0.017 \pm 0.05$ & $0.067 \pm 0.14$ & $0.033 \pm 0.11$ & $0.750 \pm 0.26$ & $0.790 \pm 0.19$ \\
\hline 8 & $0.188 \pm 0.21$ & $0.013 \pm 0.04$ & $0.000 \pm 0.00$ & $0.025 \pm 0.08$ & $0.787 \pm 0.17$ & $0.805 \pm 0.17$ \\
\hline 10 & $0.090 \pm 0.13$ & $0.020 \pm 0.04$ & $0.010 \pm 0.03$ & $0.130 \pm 0.22$ & $0.780 \pm 0.33$ & $0.869 \pm 0.21$ \\
\hline 12 & $0.192 \pm 0.18$ & $0.008 \pm 0.03$ & $0.000 \pm 0.00$ & $0.167 \pm 0.25$ & $0.558 \pm 0.38$ & $0.668 \pm 0.32$ \\
\hline LSD & *N.S. & N.S. & N.S. & N.S. & N.S. & N.S. \\
\hline \multicolumn{7}{|c|}{$25^{\circ} \mathrm{C}$} \\
\hline 6 & $0.133 \pm 0.15$ & $0.017 \pm 0.05$ & $0.000 \pm 0.00$ & $0.033 \pm 0.07$ & $0.817 \pm 0.21 \mathrm{a}$ & $0.840 \pm 0.18$ \\
\hline 8 & $0.300 \pm 0.13$ & $0.013 \pm 0.04$ & $0.038 \pm 0.06$ & $0.112 \pm 0.14$ & $0.613 \pm 0.26 \mathrm{ab}$ & $0.696 \pm 0.19$ \\
\hline 10 & $0.290 \pm 0.21$ & $0.020 \pm 0.06$ & $0.030 \pm 0.07$ & $0.170 \pm 0.28$ & $0.490 \pm 0.28 b$ & $0.610 \pm 0.21$ \\
\hline 12 & $0.233 \pm 0.17$ & $0.058 \pm 0.09$ & $0.008 \pm 0.03$ & $0.108 \pm 0.09$ & $0.600 \pm 0.22 \mathrm{ab}$ & $0.678 \pm 0.19$ \\
\hline LSD & N.S. & N.S. & N.S. & N.S. & 0.222 & N.S. \\
\hline
\end{tabular}

* means non-significant differences in (column) between the means $(p<0.05)$, according to LSD multiple; ${ }^{1}$ the percentage of seeds per treatment; ${ }^{2}$ portion of the seeds that did not initiate germination; ${ }^{3}$ seeds that started germination of the total examined seeds per treatment; ${ }^{4}$ percentage of germinated seeds with only radicles after ten days of incubation; ${ }^{5}$ percentage of seedlings with short plumules (shorter than approximately $4 \mathrm{~cm}$ ) after ten days of incubation; ${ }^{6}$ percentage of seedlings with normal plumule length after ten days of incubation; 7 the aggregated value following Equation (2) of the four categorized groups: number of non-germinated seeds, germination with the only radicle, seedling with a short plumule, and normal seedling.

\subsection{Antifungal Experiment}

This study section presents the experiment conducted to find a specific technique to prevent fungal growth in Petri dishes. At higher temperatures, fungal growth increases compared to lower temperatures. This fungal growth affects the measurements of study parameters. Although the treatment prevented fungal growth, the antifungal, Amistar Xtra, negatively affected seedling growth (Figure 9). The maize seeds grown in a media containing Hypo showed a positive effect, stimulating germination and reducing fungal growth, but no significant effect on seedling growth compared to the control. Figure 10 presents a reverse relationship between the fungicide concentration and seedling growth and development when applied to the growth media. The lowest antifungal concentration, 10 ppm, contributed to better seedling growth, but less than the control. Figure 11 presents the effect of two different techniques, priming with fungi sterilizer solution and applying antifungal, used to prevent fungal growth. The seed priming technique showed a significantly much better effect on seedling growth than the other one.

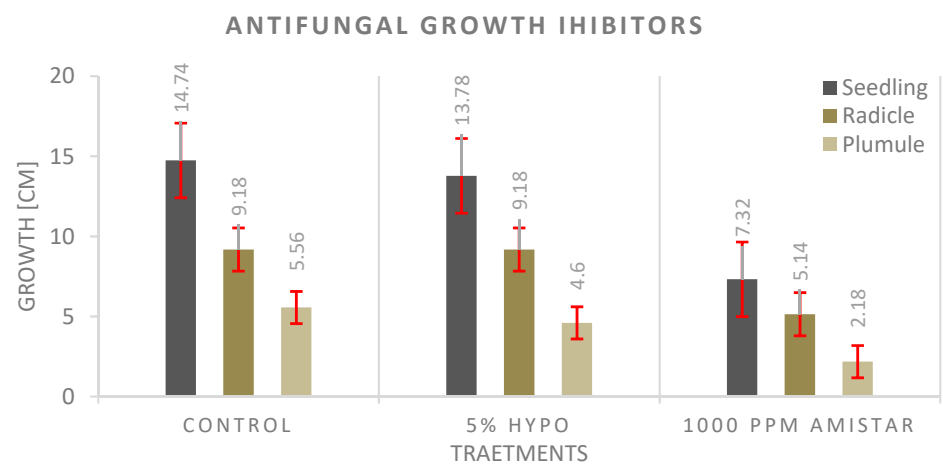

Figure 9. Seedling, radicle, and plumule performance using antifungal and Hypo growth media. LSD value is 3.56 . 


\section{ANTIFUNGAL TREATMENTS}

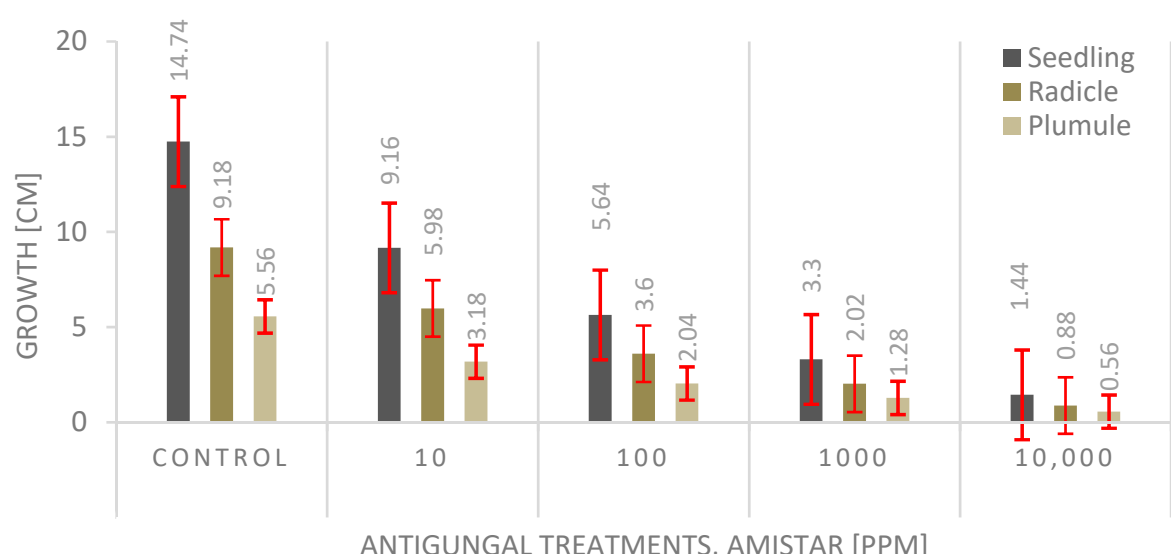

Figure 10. Seedling, radicle, and plumule performance using different concentrations of antifungal growth media. LSD value is 2.64 .

STERILIZATION METHODS

- Rinsing solution [1000 ppm] Amistar G Gowth media [1000 ppm] Amistar

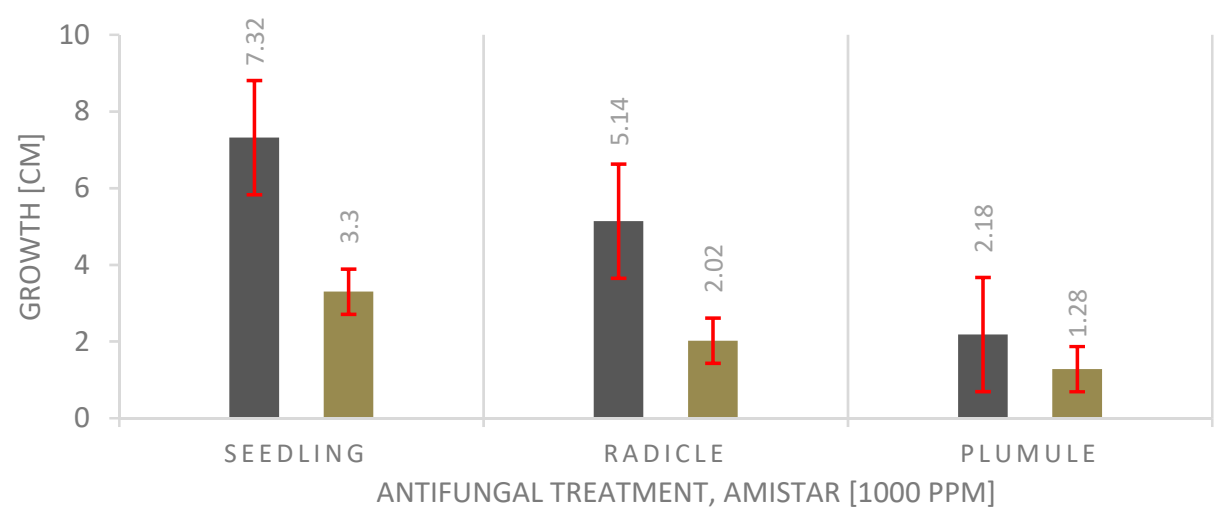

Figure 11. Seedling, radicle, and plumule performance using 2 fungal prevention techniques (seeds were primed with sterilizer solution and antifungal media). LSD value is 1.66.

\section{Discussion}

\subsection{Temperature Experiment}

\subsubsection{Germination Duration}

Temperature is critical in determining the duration of germination of the seeds [57]. The results indicate that the seeds accumulated heat units from the acquired thermal energy, and when they reached the necessary level to initiate metabolic activity, germination began at a different rate depending on the surrounding temperature condition [58]. Following the temperature gradient experiment, the range from 20 to $35{ }^{\circ} \mathrm{C}$ rapidly initiated germination with no significant differences in reaching the same germination point among this range (Figure 2). However, moderate temperatures around $20-30{ }^{\circ} \mathrm{C}$ are necessary for a maize seed to initiate germination. The cell energy state and the activities of the enzymes changed, there was a severe reduction in protein synthesis, and the ATP content increased significantly as the temperature increased higher than this level [39]. Germination at $15{ }^{\circ} \mathrm{C}$ required a longer time, that is, seven days from the start of the treatment, as confirmed by other studies [59]. The seeds needed an extended time duration up to 34 days to reach the standard measurement point of germination at $10^{\circ} \mathrm{C}$ (Figure 2). Maize seeds failed to germinate at $5^{\circ} \mathrm{C}$, although they were monitored for 45 days and at $40{ }^{\circ} \mathrm{C}$. In the literature, one study concluded that the minimum germination limit for maize seed germination is $6.2{ }^{\circ} \mathrm{C}$. The same study stated that the maize seeds could not germinate at a higher temperature than $45^{\circ} \mathrm{C}$ [60]. In this current study, maize seeds could not germinate even at $40{ }^{\circ} \mathrm{C}$, because they were subjected to a constant temperature. When the temperature 
fluctuated between the day and the night, $45^{\circ} \mathrm{C}$ was the upper limit for the seed's germination. Another reason for this might be attributed to the tested variety adaptation, because, in Hungary, the temperature is lower than the normal temperature in a tropical zone. The same seeds from the 5 and $40{ }^{\circ} \mathrm{C}$ treatments were tested at $20^{\circ} \mathrm{C}$, and the results showed that the germs were tied under a constant $40{ }^{\circ} \mathrm{C}$, but only about $30 \%$ of those seeds from the $5{ }^{\circ} \mathrm{C}$ treatment germinated. The percentage difference within the range of germination between the lower and upper limits was $177.778 \%$. The temperatures of 20,25 , and $30^{\circ} \mathrm{C}$ resulted in minor margin differences in germination duration and inner biological activities.

\subsubsection{Seedling Growth}

The best performance and the most remarkable seedling growth rate occurred at $20{ }^{\circ} \mathrm{C}$ compared to the other tested constant temperatures (Figures 2 and 3). This shows that a constant temperature of $20^{\circ} \mathrm{C}$ is the optimal temperature for maize seedling growth, a finding which deviates slightly from those of other studies that state a starting point of $23{ }^{\circ} \mathrm{C}$ for optimal growth. The results are because of the accumulation of the temperature in vitro at a constant temperature, but with fluctuating temperatures between day and night, the optimal range is slightly higher. The same pattern, but with slower growth performance, was shown at $15^{\circ} \mathrm{C}$, which was also attributed to the accumulation of the required temperature units for each growth stage. It is a longer duration for the same reason as for seedling development at $10^{\circ} \mathrm{C}$. Almost a similar growth pattern to that of the $10{ }^{\circ} \mathrm{C}$ treatment was shown at $35^{\circ} \mathrm{C}$, but it was much faster (Table 3); this is because the negative effect of the high temperature on enzymic activities, protein synthesis, and ATP content increased and because of the formation of ROS, not because of the temperature accumulation $[42,43,47,58,59]$. Slightly similar growth development appeared at 25 and $30{ }^{\circ} \mathrm{C}$ when in the early seedling stage; they grew faster, followed by slowing growth (Figure 3), because different seedling growth states demand different temperature levels. This means that each stage of seedling growth requires a different temperature level. The upper germination ranges of 30 and $35^{\circ} \mathrm{C}$ provide faster germination and very early seedling growth, but not for the following period of seedling development. Therefore, the optimal starting point for seedling development is $20^{\circ} \mathrm{C}$ with a high growth and development rate (Figure 3).

The growth and development patterns of the plumule and radicle are similar at and around the optimum temperature range, but their growth behavior varies as the temperature increases or decreases from this range (Figures 4 and 5). It seems that the plumule developed better than the radicle when the temperature is slightly higher than the optimal range, especially during the early development seedling stages (Figure 4). Radicle development has a distinctly different pattern in response to temperature, and it develops better than the plumule at a slightly lower temperature than the optimal range of the whole seedling growth, particularly in the later stage (Figure 5). As the temperature increases or decreases, either the plumule or the radicle is affected more than the other. The radicle can tolerate the cold more than the plumule, and in a reverse way, the plumule can tolerate a temperature higher than the optimal level better than the radicle.

\subsection{Water Amount Experiment}

One of the most remarkable seed quality and seed performance tests is the germination test, which is always linked to vigor tests, such as a seedling growth test [61,62]. Water uptake and temperature analyses can provide several wheat seed quality indices regarding stress tolerance, uniformity, and germination rate. Moisture availability can critically influence seed germination [63]. Maize has germination needs comparable to those of many cereal crops [64]. Crop seeds with challenging germination requirements can establish more successfully than those with limited restrictions [65]. The water amount experiment was conducted on two bases in $1 \mathrm{~mL}$ intervals from 0 to $12 \mathrm{~mL}$ and a water percentage based on the TKW to form a method in which different wheat varieties with different TKW can be 
compared in a further experiment. These two bases were examined in parallel to compare and investigate, with perter reflectance representing water demands, at each temperature level of 20 and $25{ }^{\circ} \mathrm{C}$ (Table 2).

At both temperature levels, there were significant differences among water amount potential for all the studied variables, namely, the number of non-germinated seeds, radicle length, plumule length, total seedling length, total seedling dry weight, and corrected total seedling dry weight, which were obtained by subtracting the number of non-germinated seeds, radicle dry weight, and plumule dry weight. These significant variations were shown for all variables at $25^{\circ} \mathrm{C}$, but with different patterns to those at $20^{\circ} \mathrm{C}$ (Table 5). This is attributed to the overlap between the temperature and water amount. A higher water level coincides with a higher temperature level, negatively affecting germination and seedling development.

The result shows a potential water level for germination. The number of germinated seeds increased significantly as the water level increased until it reached the optimal water amount level, followed by a slight reduction as the water amount increased because of waterlogging. This is attributed to the required water limit necessary to activate metabolic and physiological activities to start germination and to the oxygen availability in the higher amount of water. Oxygen is essential for germination initiation [1]. When applying water levels higher than the optimal range, oxygen availability for the seeds decreased. Therefore, the higher the water amount, the less the available oxygen. The same pattern was shown when applying water amounts based on the TKW with significant differences. The germination percentage at $20^{\circ} \mathrm{C}$ differed slightly with better performance than that at $25{ }^{\circ} \mathrm{C}$ because of the enzymic changes with the higher temperature $[8,42,43]$. Since water is a fundamental element for germination, seed germination can occur at moistures close to the wilting point enough to activate germination metabolism. Seeds would not germinate if the internal moisture was below the critical moisture limit. Maize seeds can be germinated when applying a minimal amount of water, $0.60 \mathrm{~mL}$, representing $25 \%$ of the TKW, and the optimal for germination is between 2.95 and $5.3 \mathrm{~mL}$ per $9 \mathrm{~cm}$ Petri dish, representing 125 and $225 \%$ of the TKW (Table 2 ).

When applying the lowest amount of water, the seedling length presented with the lowest mean values, and as the amount of water increased, seedling development significantly increased. The optimal range of the water amount for seedling growth was between 3.55 and $7.65 \mathrm{~mL}$ per $9 \mathrm{~cm}$ Petri dish, representing 150 and 325\% of the TKW, at $20{ }^{\circ} \mathrm{C}$. This optimal range differed at $25{ }^{\circ} \mathrm{C}$, ranging from 100 to $225 \%$ of the TKW because of the temperature overlap with the water level in a relatively reverse relationship to some degree. The range of the optimal water amount was wider at $20^{\circ} \mathrm{C}$ than at $25^{\circ} \mathrm{C}$, which might be because of the increased effect of a higher temperature on membrane permeability, and as a result, seeds became watery and oversaturated. Water stress significantly reduces seedlings' vigor, seedling length increases dramatically at the starting point of the optimal range, and moisture percentage based on the TKW is more accurate and reliable.

The maize radicle's growth gradually decreased as the amount of water increased over the optimal range. Plumule growth and development followed a different pattern from that of the growth of the radicle. Therefore, it is reasonable to measure the whole seedling; the radicle and the plumule statistically continued to be close to the optimal range as the water increased. Water stress and waterlogging had a greater effect on the roots than on the plumules. This can be attributed to the physiological aspect of radicle growth; when there was enough water, the plant exhibited slower root growth and accelerated shoot growth. The plumule-accumulated dry matter unit required more water than a unit of root dry matter. This result is consistent with the result reported by [66], where the authors assessed the impact of water potential ( 0 and $-0.2 \mathrm{MPa})$ and temperature $(20,25$, and $30{ }^{\circ} \mathrm{C}$ ) on the germination of Pinus yunnanensis seeds. Water availability highly affected the germination percentage, seedling growth rate, and the accumulated dry matter: the more severe the hydro stress, the more significant the reduction in these traits' values. There are 
hydro limitations and potential ranges for each state of germination and seedling growth, as presented in other studies [67].

More than half of the seeds were germinated with $0.65 \mathrm{~mL}$ of water. Therefore, water application based on the TKW provides a better understanding of determining the limits and the optimum water requirement because seed size plays an essential role in reaching the necessary internal seed moisture. By comparison, these results align with a study by [66], reporting that "seed size has importance in predicting germination under stress conditions".

\subsection{Seed Number Experiment}

The results address which seed numbers are essential in seedling elongation bioassays in vitro. The larger water volumes or the lower wheat seedling densities increase the quantity of phytotoxin present per seed and increase inhibition [68]. A seedling density higher than the optimum number negatively affects seedling growth in a Petri dish when opening the Petri dish cover. It creates exposure to water losses and, finally, seedling growth insufficiency. The results of the statistical analysis of variance present no significant differences between the germination percentages with different treatments and seedling densities. Furthermore, there were no significant differences among the subdivisions of the aggregated values. Since a higher seedling density than the optimum resulted in a reverse effect when opening the Petri dish cover, and there were no significant differences between the four seed densities in use, it was concluded that a density of six seeds per Petri dish is better for maize germination tests. In the case of plant breeding projects (identical seeds are sometimes in shortage), studying the optimal number of seeds necessary to use in a Petri dish experiment is essential. It assists in optimizing the usage of resources, especially for plant breeders.

\subsection{Antifungal Experiment}

Fungal growth negatively affects seed germination and seedling growth. Fungal growth increased as the temperature increased, even in vitro [69]. This fungal growth affects the measurements of study parameters by negatively impacting plumules and radicles. This study was partly designed to find a specific technique to prevent fungal growth in vitro. Although the antifungal, Amistar Xtra, prevented fungal growth, it negatively affected seedling growth. It harms the cell's osmotic pressure and the water uptake by the seeds. Therefore, the germination percentages and seedling development were highly affected as the antifungal concentration increased in the growth media. Although Hypo presented the positive effect of stimulating germination and reducing fungal growth, it showed no significance in seedling growth compared to the control, which was slightly lower. The effect of the two different techniques, priming with fungi sterilizer solution and applying antifungal, used to prevent fungal growth was noticeable. The literature regarding antifungal activity on seed germination states that antifungal inhibits and damages hyphae in vitro [70]. It damages DNA and protein and reduces the GSH content of the fungus. Therefore, antifungals prevent maize seed germination problems and mycotoxicosis on maize kernels [70]. The seed priming technique shows a significantly much better effect on seedling growth than adding the antifungal to the growth media. It can be stated that sterilizing seeds with a minimum antifungal, less than $1000 \mathrm{ppm}$, can reduce fungal growth in vitro.

\section{Conclusions}

- The sigmoid curves have a solid fit for the experimental data of germination and seedling growth temperatures. The optimal temperature for seedling growth is $20^{\circ} \mathrm{C}$, and a more comprehensive range for germination is from 20 to $35^{\circ} \mathrm{C}$. A temperature lower than the optimal range decreases the germination rate, and a higher temperature increases fungal growth. 
- Seed size influences the quantity of water needed for germination. Therefore, TKW provides a more accurate perspective for water amount application. Germination in different percentages can occur in a wide range of water amounts starting at $0.60 \mathrm{~mL}$, representing $25 \%$ of the maize TKW, but the optimal range for germination is $0.06-5.30 \mathrm{~mL}$, representing $25-225 \%$ of the TKW. The optimal range for seedling growth is $2.35-7.75 \mathrm{~mL}$. As the temperature increases, the optimal range for the water amount narrows; e.g., at $20^{\circ} \mathrm{C}$, it is broader than at $25^{\circ} \mathrm{C}$.

- Dry weight can indicate seedling development, because dry matter accumulation is consistent with the physical measurement of seedling growth.

- Different seed and seedling densities present no significant difference; thus, using a lower seed density is recommended for lab examination: six maize seeds per $9 \mathrm{~cm}$ PD.

- The seed priming technique before planting shows a significantly much better effect on seedling growth than adding the antifungal to the growth media, and the highest values were recorded with the control.

In brief, this study recommends conducting maize seed germination and seedling growth experiments at $20^{\circ} \mathrm{C}$, applying the water amount as a percentage of the TKW for optimization of the water amount suitability, and using a density of no more than six seeds per Petri dish since there is no significance of using a higher number of seeds. This is common practice in the case of seed limitation and breeding projects.

Author Contributions: Methodology, writing—original paper, H.K.; methodology, Z.K.; reviewing, M.J.; funding acquisition, G.P.K.; acquisition, C.G.; conceptualization, reviewing, Á.T. All authors have read and agreed to the published version of the manuscript.

Funding: This research was funded by the Hungarian University of Agriculture and Life Sciences. Stipendium Hungaricum Foundation supported it.

Institutional Review Board Statement: Not applicable.

Informed Consent Statement: Not applicable.

Data Availability Statement: All data, tables, and figures in this manuscript are original.

Acknowledgments: The authors would like to express high gratitude to Kovács Zsófia from the genetic department, for her magnificent notes and work. Our gratitude is extended to the lab-tech, Katalin Dobine, for assisting in the experiment. This work was carried out within the framework of the Thematic Program of Excellence with support of the project TKP2020-NKA-24 entitled "Protein Feed Program for the Qualitative and Quantitative Development of Hungarian Agriculture and the Strengthening of the Welfare of Society". We would like to thank the financial support of Researchers Recruitment Programme of National Agricultural Research and Innovation Centre (Gödöllő, Hungary).

Conflicts of Interest: The authors declare no conflict of interest.

\section{References}

1. Xue, X.; Du, S.; Jiao, F.; Xi, M.; Wang, A.; Xu, H.; Jiao, Q.; Zhang, X.; Jiang, H.; Chen, J.; et al. The regulatory network behind maize seed germination: Effects of temperature, water, phytohormones, and nutrients. Crop J. 2021, 9, 901-914. [CrossRef]

2. Sakina; Khan, A.S.; Nasrullah, A.; Ullah, F.; Muhammad, N.; Kubra, S.; Din, I.U.; Mutahir, Z. Effect of imidazolium's ionic liquids with different anions and alkyl chain length on phytotoxicity and biochemical analysis of maize seedling. J. Mol. Liq. 2021, 321, 114491. [CrossRef]

3. Yang, B.; Yin, Y.; Liu, C.; Zhao, Z.; Guo, M. Effect of germination time on the compositional, functional and antioxidant properties of whole wheat malt and its end-use evaluation in cookie-making. Food Chem. 2021, 349, 129125. [CrossRef] [PubMed]

4. Ranum, P.; Peña-Rosas, J.P.; Garcia-Casal, M.N. Global maize production, utilization, and consumption. Ann. N. Y. Acad. Sci. 2014, 1312, 105-112. [CrossRef]

5. Sarwar, N.; Atique-ur-Rehman; Farooq, O.; Wasaya, A.; Hussain, M.; El-Shehawi, A.M.; Ahmad, S.; Brestic, M.; Mahmoud, S.F.; Zivcak, M.; et al. Integrated nitrogen management improves productivity and economic returns of wheat-maize cropping system. J. King Saud Univ.-Sci. 2021, 33, 101475. [CrossRef]

6. Cakmak, I.; Prom-u-thai, C.; Guilherme, L.R.G.; Rashid, A.; Hora, K.H.; Yazici, A.; Savasli, E.; Kalayci, M.; Tutus, Y.; Phuphong, P.; et al. Iodine biofortification of wheat, rice and maize through fertilizer strategy. Plant Soil 2017, 418, 319-335. [CrossRef]

7. Tollenaar, M.; Lee, E.A. Yield potential, yield stability and stress tolerance in maize. Field Crops Res. 2002, 75, 161-169. [CrossRef] 
8. Crafts-Brandner, S.J.; Salvucci, M.E. Sensitivity of photosynthesis in a C4 plant, maize, to heat stress. Plant Physiol. 2002, 129, 1773-1780. [CrossRef]

9. Wang, T.; Zang, Z.; Wang, S.; Liu, Y.; Wang, H.; Wang, W.; Hu, X.; Sun, J.; Tai, F.; He, R. Quaternary ammonium iminofullerenes promote root growth and osmotic-stress tolerance in maize via ROS neutralization and improved energy status. Plant Physiol. Biochem. 2021, 164, 122-131. [CrossRef]

10. Li, Y.; Shan, X.; Jiang, Z.; Zhao, L.; Jin, F. Genome-wide identification and expression analysis of the GA2ox gene family in maize (Zea mays L.) under various abiotic stress conditions. Plant Physiol. Biochem. 2021, 166, 621-633. [CrossRef]

11. Herman, J.J.; Sultan, S.E.; Horgan-Kobelski, T.; Riggs, C. Adaptive transgenerational plasticity in an annual plant: Grandparental and parental drought stress enhance performance of seedlings in dry soil. Integr. Comp. Biol. 2012, 52, 77-88. [CrossRef] [PubMed]

12. Poudel, R.; Finnie, S.; Rose, D.J. Effects of wheat kernel germination time and drying temperature on compositional and end-use properties of the resulting whole wheat flour. J. Cereal Sci. 2019, 86, 33-40. [CrossRef]

13. Pangapanga-Phiri, I.; Mungatana, E.D. Adoption of climate-smart agricultural practices and their influence on the technical efficiency of maize production under extreme weather events. Int. J. Disaster Risk Reduct. 2021, 61, 102322. [CrossRef]

14. Gallardo, K.; Job, C.; Groot, S.P.C.; Puype, M.; Demol, H.; Vandekerckhove, J.; Job, D. Proteomic analysis of Arabidopsis seed germination and priming. Plant Physiol. 2001, 126, 835-848. [CrossRef]

15. MEI, Y.Q.; Song, S.Q. Early Morphological and Physiological Events Occurring During Germination of Maize Seeds. Agric. Sci. China 2008, 7, 950-957. [CrossRef]

16. FU, F.F.; Peng, Y.S.; Wang, G.B.; EL-kassaby, Y.A.; Cao, F.L. Integrative analysis of the metabolome and transcriptome reveals seed germination mechanism in Punica granatum L. J. Integr. Agric. 2021, 20, 132-146. [CrossRef]

17. Koornneef, M.; Bentsink, L.; Hilhorst, H. Seed Dormancy and Germination. Curr. Opin. Plant Biol. 2002, 5, 33-36. [CrossRef]

18. Bewley, J.D.; Black, M. Seeds.Physiology of Development and Germination, 2nd ed.; Springer Science \& Business Media: Berlin, Germany, 1994; p. 421.

19. Masubelele, N.H.; Dewitte, W.; Menges, M.; Maughan, S.; Collins, C.; Huntley, R.; Nieuwland, J.; Scofield, S.; Murray, J.A.H. D-type cyclins activate division in the root apex to promote seed germination in Arabidopsis. Proc. Natl. Acad. Sci. USA 2005, 102, 15694-15699. [CrossRef]

20. Itroutwar, P.D.; Kasivelu, G.; Raguraman, V.; Malaichamy, K.; Sevathapandian, S.K. Effects of biogenic zinc oxide nanoparticles on seed germination and seedling vigor of maize (Zea mays). Biocatal. Agric. Biotechnol. 2020, 29, 101778. [CrossRef]

21. Nciizah, A.D.; Rapetsoa, M.C.; Wakindiki, I.I.; Zerizghy, M.G. Micronutrient seed priming improves maize (Zea mays) early seedling growth in a micronutrient deficient soil. Heliyon 2020, 6, e04766. [CrossRef]

22. Shah, T.; Latif, S.; Khan, H.; Munsif, F.; Nie, L. Ascorbic acid priming enhances seed germination and seedling growth of winter wheat under low temperature due to late sowing in Pakistan. Agronomy 2019, 9, 757. [CrossRef]

23. Vishal, B.; Kumar, P.P. Regulation of seed germination and abiotic stresses by gibberellins and abscisic acid. Front. Plant Sci. 2018, 9, 838. [CrossRef] [PubMed]

24. Lara-Núñez, A.; Romero-Sánchez, D.I.; Axosco-Marín, J.; Garza-Aguilar, S.M.; Gómez-Martínez, A.E.; Ayub-Miranda, M.F. Bravo-Alberto, C.E.; Vázquez-Santana, S.; Vázquez-Ramos, J.M. Two cyclin Bs are differentially modulated by glucose and sucrose during maize germination. Biochimie 2021, 182, 108-119. [CrossRef] [PubMed]

25. Kildisheva, O.A.; Dixon, K.W.; Silveira, F.A.O.; Chapman, T.; Di Sacco, A.; Mondoni, A.; Turner, S.R.; Cross, A.T. Dormancy and germination: Making every seed count in restoration. Restor. Ecol. 2020, 28, S256-S265. [CrossRef]

26. Rizzardi, M.A.; Luiz, A.R.; Roman, E.S.; Vargas, L. Temperatura cardeal e potencial hídrico na germinação de sementes de corda-de-viola (Ipomoea triloba). Planta Daninha 2009, 27, 13-21. [CrossRef]

27. McCormick, M.K.; Taylor, D.L.; Whigham, D.F.; Burnett, R.K. Germination patterns in three terrestrial orchids relate to abundance of mycorrhizal fungi. J. Ecol. 2016, 104, 744-754. [CrossRef]

28. Cone, J.W.; Spruit, C.J.P. Imbibition conditions and seed dormancy of Arabidopsis thaliana. Physiol. Plant. 1983, 59, 416-420. [CrossRef]

29. Chakraborti, S.; Bera, K.; Sadhukhan, S.; Dutta, P. Bio-priming of seeds: Plant stress management and its underlying cellular, biochemical and molecular mechanisms. Plant Stress 2022, 3, 100052. [CrossRef]

30. Ozden, E.; Light, M.E.; Demir, I. Alternating temperatures increase germination and emergence in relation to endogenous hormones and enzyme activities in aubergine seeds. S. Afr. J. Bot. 2021, 139, 130-139. [CrossRef]

31. Norgrove, L. Trade-offs in maize seedling losses in African grasslands. Crop Prot. 2021, 146, 105676. [CrossRef]

32. Focks, N.; Benning, C. Wrinkled1: A Novel, Low-Seed-Oil Mutant of Arabidopsis with a Deficiency in the Seed-Specific Regulation of Carbohydrate Metabolism 1. Plant Physiol. 1998, 118, 91-101. [CrossRef] [PubMed]

33. Prerna, D.I.; Govindaraju, K.; Tamilselvan, S.; Kannan, M.; Vasantharaja, R.; Chaturvedi, S.; Shkolnik, D. Influence of nanoscale micro-nutrient $\alpha-\mathrm{Fe}_{2} \mathrm{O}_{3}$ on seed germination, seedling growth, translocation, physiological effects and yield of rice (Oryza sativa) and maize (Zea mays). Plant Physiol. Biochem. 2021, 162, 564-580. [CrossRef] [PubMed]

34. Bradford, K.J.; Nonogaki, H. Annual Plant Reviews, Seed Development, Dormancy and Germination; Wiley-Blackwell: Oxford, UK, 2007; pp. 1-367. [CrossRef]

35. Díaz-Granados, V.H.; López-López, J.M.; Flores-Sánchez, J.; Olguin-Alor, R.; Bedoya-López, A.; Dinkova, T.D.; Salazar-Díaz, K.; Vázquez-Santana, S.; Vázquez-Ramos, J.M.; Lara-Núñez, A. Glucose modulates proliferation in root apical meristems via TOR in maize during germination. Plant Physiol. Biochem. 2020, 155, 126-135. [CrossRef] 
36. Farooq, M.; Hussain, M.; Wakeel, A.; Siddique, K.H.M. Salt stress in maize: Effects, resistance mechanisms, and management. A review. Agron. Sustain. Dev. 2015, 35, 461-481. [CrossRef]

37. Deng, B.; Yang, K.; Zhang, Y.; Li, Z. Can heavy metal pollution defend seed germination against heat stress? Effect of heavy metals $\left(\mathrm{Cu}^{2+}, \mathrm{Cd}^{2+}\right.$ and $\left.\mathrm{Hg}^{2+}\right)$ on maize seed germination under high temperature. Environ. Pollut. 2016, 216, 46-52. [CrossRef]

38. Khalid, N.; Tarnawa, Á.; Kende, Z.; Kassai, K.M.; Jolánkai, M. Viability of maize (Zea mays L.) seeds influenced by water, temperature, and salinity stress. Acta Hydrol. Slovaca 2021, 22, 113-117. [CrossRef]

39. Riley, G.J.P. Effects of High Temperature on the Germination of Maize (Zea mays L.). Planta 1981, 151, 68-74. [CrossRef]

40. Bailly, C. The signalling role of ROS in the regulation of seed germination and dormancy. Biochem. J. 2019, 476, 3019-3032. [CrossRef]

41. Gong, M.; Chen, B.O.; Li, Z.G.; Guo, L.H. Heat-shock-induced cross adaptation to heat, chilling, drought and salt stress in maize seedlings and involvement of $\mathrm{H}_{2} \mathrm{O}_{2}$. J. Plant Physiol. 2001, 158, 1125-1130. [CrossRef]

42. Ostadian Bidgoly, R.; Balouchi, H.; Soltani, E.; Moradi, A. Effect of temperature and water potential on Carthamus tinctorius L. seed germination: Quantification of the cardinal temperatures and modeling using hydrothermal time. Ind. Crops Prod. 2018, 113, 121-127. [CrossRef]

43. Dadach, M.; Mehdadi, Z.; Latreche, A. Effect of water stress on seed germination of Thymus serpyllum L. from Tessala mount. J. Plant Sci. 2015, 10, 151-158. [CrossRef]

44. Yousefi, A.R.; Rashidi, S.; Moradi, P.; Mastinu, A. Germination and seedling growth responses of zygophyllum fabago, salsola kali 1. And atriplex canescens to peg-induced drought stress. Environments 2020, 7, 107. [CrossRef]

45. Andronis, E.A.; Moschou, P.N.; Toumi, I.; Roubelakis-Angelakis, K.A. Peroxisomal polyamine oxidase and NADPH-oxidase cross-talk for ROS homeostasis which affects respiration rate in Arabidopsis thaliana. Front. Plant Sci. 2014, 5, 132. [CrossRef]

46. Guan, B.; Zhou, D.; Zhang, H.; Tian, Y.; Japhet, W.; Wang, P. Germination responses of Medicago ruthenica seeds to salinity, alkalinity, and temperature. J. Arid Environ. 2009, 73, 135-138. [CrossRef]

47. Yan, M.; Xue, C.; Xiong, Y.; Meng, X.; Li, B.; Shen, R.; Lan, P. Proteomic dissection of the similar and different responses of wheat to drought, salinity and submergence during seed germination. J. Proteom. 2020, 220, 103756. [CrossRef] [PubMed]

48. Bradford, K.J. A water relations analysis of seed germination rates. Plant Physiol. 1990, 94, 840-849. [CrossRef]

49. Liu, Y.; Han, C.; Deng, X.; Liu, D.; Liu, N.; Yan, Y. Integrated physiology and proteome analysis of embryo and endosperm highlights complex metabolic networks involved in seed germination in wheat (Triticum aestivum L.). J. Plant Physiol. 2018, 229, 63-76. [CrossRef] [PubMed]

50. Marcos-Filho, J. Seed vigor testing: An overview of the past, present and future perspective. Sci. Agric. 2015, 72, 363-374. [CrossRef]

51. Abido, W.A.E.; Zsombik, L. Effect of water stress on germination of some Hungarian wheat landraces varieties. Shengtai Xuebao/Acta Ecol. Sin. 2020, 38, 422-428. [CrossRef]

52. Aderounmu, A.F.; Nkemnkeng, F.J.; Anjah, G.M. Effects of seed provenance and growth media on the growth performance of Vitellaria paradoxa C.F. Gaertn. Int. J. Biol. Chem. Sci. 2020, 14, 2659-2669. [CrossRef]

53. Karimmojeni, H.; Rahimian, H.; Alizadeh, H.; Yousefi, A.R.; Gonzalez-Andujar, J.L.; Mac Sweeney, E.; Mastinu, A. Competitive ability effects of datura stramonium 1. And xanthium strumarium 1. on the development of maize (Zea mays) seeds. Plants 2021, 10, 1922. [CrossRef]

54. Fenotiana, R.V. In Vitro Experiments to Study the Effect of Stress Factors on the Germination of Maize; Hungarian University of Agriculture and Life Sciences: Gödöllő, Hungary, 2017.

55. Ahmad Samir, A. Comparative Study on Wheat Production in Afghanistan and Hungary; Hungariun University of Agriculture and Life Sciences: Gödöllő, Hungary, 2016.

56. Bulmer, M.G.; Harrison, T.K. Journal of the Royal Statistical Society. Series D. Statistician 1966, 16, 217. [CrossRef]

57. Seefeldt, S.S.; Kidwell, K.K.; Waller, J.E. Base growth temperatures, germination rates and growth response of contemporary spring wheat (Triticum aestivum L.) cultivars from the US Pacific Northwest. Field Crops Res. 2002, 75, 47-52. [CrossRef]

58. Boyce, D.S. Heat and moisture transfer in ventilated grain. J. Agric. Eng. Res. 1966, 11, 255-265. [CrossRef]

59. Guan, Y.J.; Hu, J.; Wang, X.J.; Shao, C.X. Seed priming with chitosan improves maize germination and seedling growth in relation to physiological changes under low temperature stress. J. Zhejiang Univ. Sci. B 2009, 10, 427-433. [CrossRef] [PubMed]

60. Sánchez, B.; Rasmussen, A.; Porter, J.R. Temperatures and the growth and development of maize and rice: A review. Glob. Chang. Biol. 2014, 20, 408-417. [CrossRef] [PubMed]

61. Singh, R.; Singh, S.; Parihar, P.; Mishra, R.K.; Tripathi, D.K.; Singh, V.P.; Chauhan, D.K.; Prasad, S.M. Reactive oxygen species (ROS): Beneficial companions of plants' developmental processes. Front. Plant Sci. 2016, 7, 1299. [CrossRef] [PubMed]

62. da Silva, L.J.; de Medeiros, A.D.; Oliveira, A.M.S. SeedCalc, a new automated R software tool for germination and seedling length data processing. J. Seed Sci. 2019, 41, 250-257. [CrossRef]

63. Sabouri, A.; Azizi, H.; Nonavar, M. Hydrotime model analysis of lemon balm (melissa officinalis L.) using different distribution functions. S. Afr. J. Bot. 2020, 135, 158-163. [CrossRef]

64. Barrero, J.M.; Jacobsen, J.V.; Talbot, M.J.; White, R.G.; Swain, S.M.; Garvin, D.F.; Gubler, F. Grain dormancy and light quality effects on germination in the model grass Brachypodium distachyon. New Phytol. 2012, 193, 376-386. [CrossRef]

65. Shaban, M. Effect of water and temperature on seed germination and emergence as a seed hydrothermal time model. Int. J. Adv. Biol. Biomed. Res. 2013, 1, 1686-1691. 
66. Gao, C.; Liu, F.; Zhang, C.; Feng, D.; Li, K.; Cui, K. Germination responses to water potential and temperature variation among provenances of Pinus yunnanensis. Flora Morphol. Distrib. Funct. Ecol. Plants 2021, 276-277, 151786. [CrossRef]

67. Zhang, K.; Ji, Y.; Fu, G.; Yao, L.; Liu, H.; Tao, J. Dormancy-breaking and germination requirements of Thalictrum squarrosum Stephan ex Willd. seeds with underdeveloped embryos. J. Appl. Res. Med. Aromat. Plants 2021, 24, 100311. [CrossRef]

68. Weidenhamer, J.D.; Morton, T.C.; Romeo, J.T. Solution volume and seed number: Often overlooked factors in allelopathic bioassays. J. Chem. Ecol. 1987, 13, 1481-1491. [CrossRef] [PubMed]

69. Aldars-García, L.; Marín, S.; Sanchis, V.; Magan, N.; Medina, A. Assessment of intraspecies variability in fungal growth initiation of Aspergillus flavus and aflatoxin B1 production under static and changing temperature levels using different initial conidial inoculum levels. Int. J. Food Microbiol. 2018, 272, 1-11. [CrossRef] [PubMed]

70. Krishnan, N.; Velramar, B.; Velu, R.K. Investigation of antifungal activity of surfactin against mycotoxigenic phytopathogenic fungus Fusarium moniliforme and its impact in seed germination and mycotoxicosis. Pestic. Biochem. Physiol. 2019, 155, 101-107. [CrossRef] 